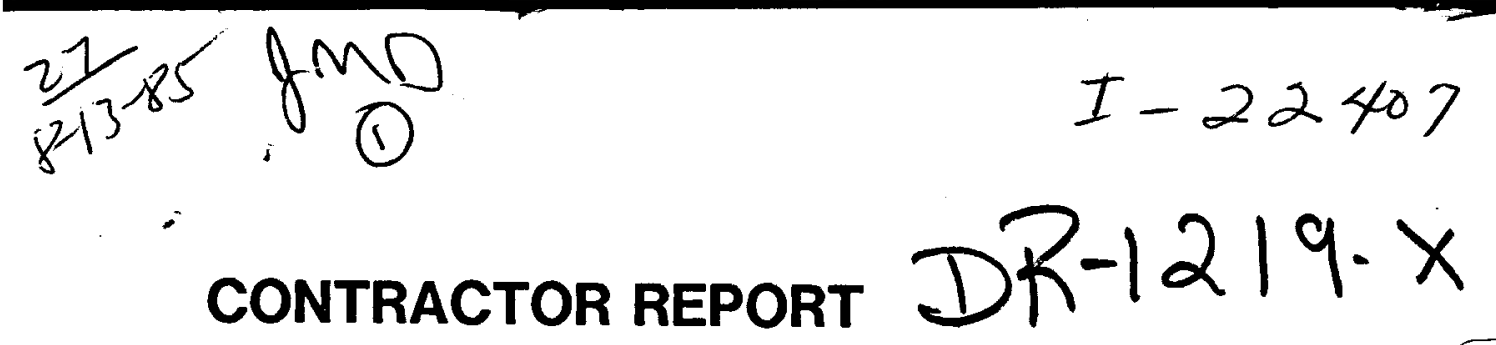

SAND84 -7178

Unlimited Release

UC -70

\title{
Assessment of Near-Surface Dissolution At and Near the Waste Isolation Pilot Plant (WIPP), Southeastern New Mexico
}

George O. Bachman, Consultant

Star Route, Box 1028

Corrales, NM 87048

Prepared by Sandia National Laboratories Albuquerque, New Mexico 87185 and Livermore, California 94550 for the United States Department of Energy under Contract DE-AC04-76DP00789

Printed July 1985 


\section{DISCLAIMER}

This report was prepared as an account of work sponsored by an agency of the United States Government. Neither the United States Government nor any agency Thereof, nor any of their employees, makes any warranty, express or implied, or assumes any legal liability or responsibility for the accuracy, completeness, or usefulness of any information, apparatus, product, or process disclosed, or represents that its use would not infringe privately owned rights. Reference herein to any specific commercial product, process, or service by trade name, trademark, manufacturer, or otherwise does not necessarily constitute or imply its endorsement, recommendation, or favoring by the United States Government or any agency thereof. The views and opinions of authors expressed herein do not necessarily state or reflect those of the United States Government or any agency thereof. 


\section{DISCLAIMER}

Portions of this document may be illegible in electronic image products. Images are produced from the best available original document. 
Issued by Sandia National Laboratories, operated for the United States Department of Energy by Sandia Corporation.

NOTICE: This report was prepared as an account of work sponsored by an agency of the United States Government. Neither the United States Government nor any agency thereof, nor any of their employees, nor any of their contractors, subcontractors, or their employees, makes any warranty, express or implied, or assumes any legal liability or responsibility for the accuracy, completeness, or usefulness of any information, apparatus, product, or process disclosed, or represents that its use would not infringe privately owned rights. Reference herein to any specific commercial product, process, or service by trade name, trademark, manufacturer, or otherwise, does not necessarily constitute or imply its endorsement, recommendation, or favoring by the United States Government, any agency thereof or any of their contractors or subcontractors. The views and opinions expressed herein do not necessarily state or reflect those of the United States Government, any agency thereof or any of their contractors or subcontractors.

Printed in the United States of America Available from

National Technical Information Service

U.S. Department of Commerce

5285 Port Royal Road

Springfield, VA 22161

NTIS price codes

Printed copy: A02

Microfiche copy: A01 


\title{
Assessment of Near-Surface Dissolution At and Near the Waste Isolation Pilot Plant (WIPP), Southeastern New Mexico
}

\author{
George O. Bachman, Consultant \\ Star Route, Box 1028 \\ Corrales, NM 87048
}

\begin{abstract}
The area at and near the WIPP site was examined for evidence of karst development on the geomorphic surface encompassing the site. Certain surficial depressions of initial concern were identified as blowouts in sand dune fields (shallow features unrelated to karstification). An ancient stream system active more than 500,000 yr ago contained more water than any system since. During that time (Gatuña, Middle Pleistocene), many karst features such as Clayton Basin and Nash Draw began to form in the region. Halite was probably dissolved from parts of the Rustler Formation at that time. Dissolution of halite and gypsum from intervals encountered in Borehole WIPP-33 west of the WIPP site occurred during later Pleistocene time (i.e., $<450,000$ yr ago). However, there is no evidence of active near-surface dissolution within a belt to the east of WIPP-33 in the vicinity of the WIPP shaft.
\end{abstract}

This document is PUBLICLY RELEASABLR

\section{DISCLAIMER}

This report was prepared as an account of work sponsored by an agency of the United States Government. Neither the United States Government nor any agency thereof, nor any of their employees, makes any warranty, express or implied, or assumes any legal liability or responsibility for the accuracy, completeness, or usefulness of any information, apparatus, product, or process disclosed, or represents that its use would not infringe privately owned rights. Reference herein to any specific commercial product, process, or service by trade name, trademark, manufacturer, or otherwise does not necessarily constitute or imply its endorsement, recommendation, or favoring by the United States Government or any agency thereof. The views and opinions of authors expressed herein do not necessarily state or reflect those of the United States Government or any agency thereof.

PUBLICLY RELEASABLA
$\frac{B \text { Steele }}{\text { Authorizing Official }}$
Date: $3 / 22 / 06$

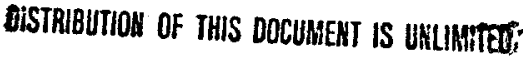




\section{Acknowledgments}

Funding for this study was provided by Sandia National Laboratories (Agreement 48-9558). SueEllen Shaffer, Sandia National Laboratories, assisted in the field work. 


\section{Contents}

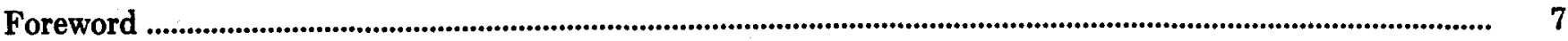

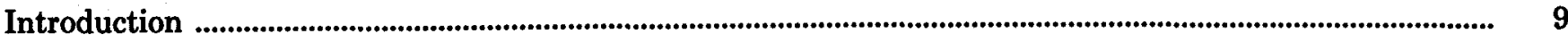



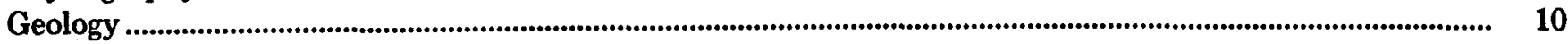







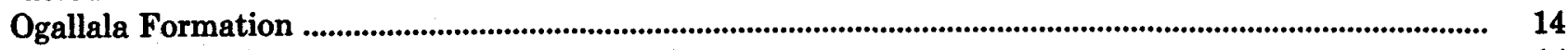

Pleistocene Deposits ............................................................................................................................................ 14

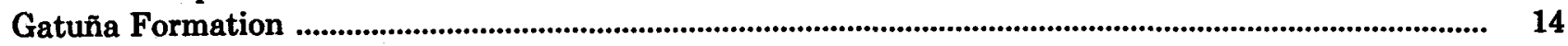

Mescalero Caliche .................................................................................................................................................. 19



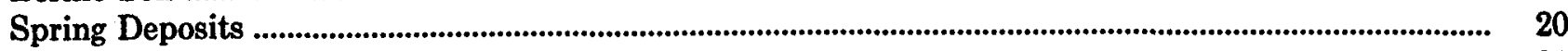

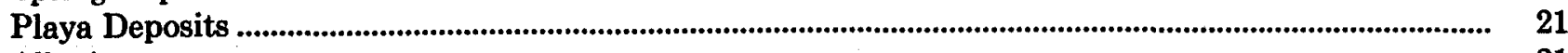

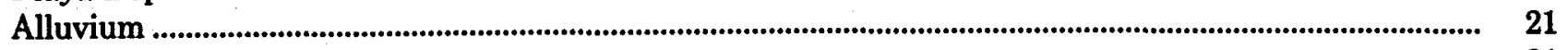

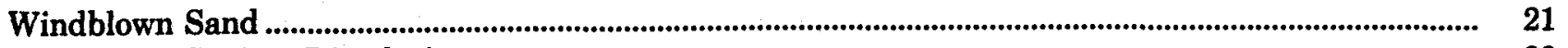

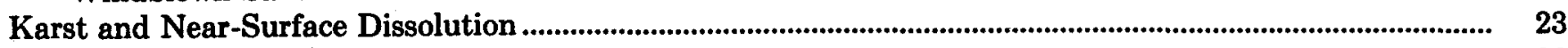

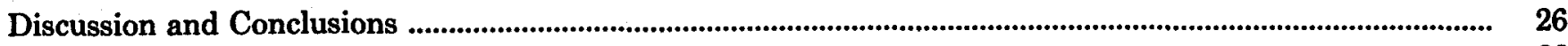

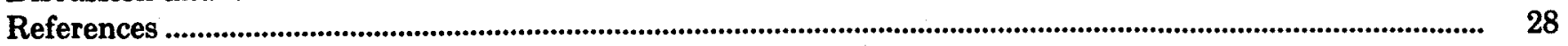

\section{Figures}

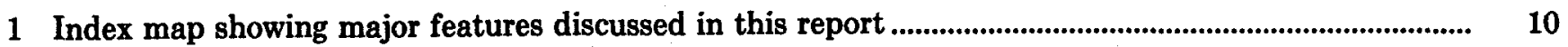

2 Isopach map of Rustler Formation .................................................................................................................. 13

3 Cross-bedded pebble conglomerate in channel deposit at base of Gatuna Formation ........................... 15

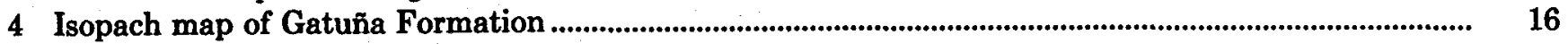

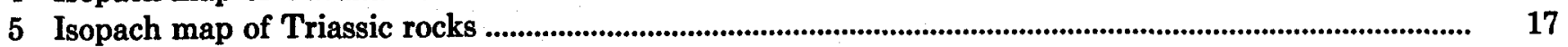

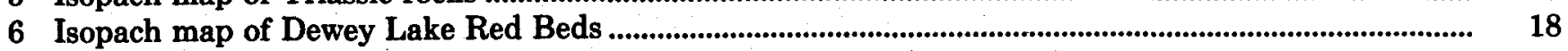

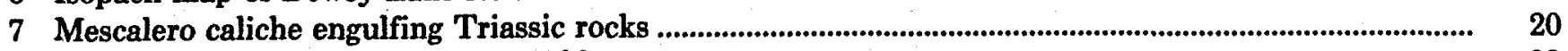

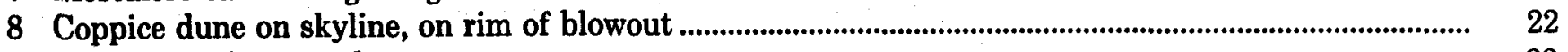

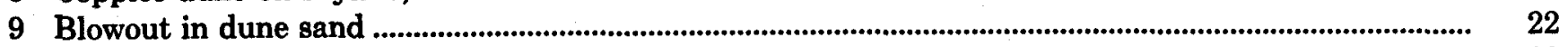

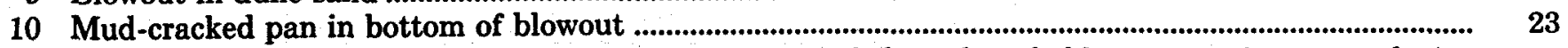

11 Map showing distribution of Gatuña Formation (stippled) and probable course of streams during Gatuña time (arrows) 



\section{Foreword}

This report is a partial accounting of work by George O. Bachman on behalf of Sandia National Laboratories as part of continued characterization of surface geology at the Waste Isolation Pilot Plant (WIPP) site. Mr. Bachman is writing a series of reports on various aspects of the surface and subsurface geology of the Delaware Basin of southeastern New Mexico. All these reports deal with dynamic geological processes as they affect the survivability of the evaporites in the Delaware Basin and the longterm integrity of the natural systems that must continue to isolate radioactive wastes emplaced in evaporites at the WIPP.

This report deals with the occurrence of the Quaternary Gatuna Formation at and near the WIPP site. In addition, the Gatuña Formation is placed into a context with respect to a major dissolution-subsidence feature (Nash Draw) and several other smaller collapse sinks. Logic leading to inferences about the origins of these various collapse features is not repeated here, as such description appears in detail in other reports by Mr. Bachman. Consequently, several of the statements made herein are not accompanied by the complete set of substantiating descriptions and discussions.

Several geomorphic features around the site (specifically, blowouts among sand dunes, sinkholes in gypsic terrain, and closed depressions at Boreholes WIPP-14 and WIPP-33) have been cited by Barrows and others (1983) as evidence of a pervasive geologic process of shallow- and deep-seated karst formation. This proposition arose from one possible interpretation of Bouguer gravity anomalies near the site. Whereas this report does not specifically attempt to reinterpret the gravity anomalies, it does make conclusions about the relationships between the paleoclimate, paleohydrology, distribution, and thickness of stream deposits of the Gatuña Formation, and about the near-surface paleodissolution in the Rustler
Formation. Channels in the Gatuña Formation may be important in interpreting the Bouguer gravity anomalies; the geological relationships described herein may suggest alternative explanations for the Bouguer gravity anomalies other than deep-seated pervasive karst. Whereas this report does not specifically attempt to evaluate all the various implications of karstic terrain with respect to groundwater movement, it provides some background for other reports that will directly discuss this issue, many of which will use laboratory and numerical methods as well as field mapping. In addition it concludes that "true karst features should not be predicted on the Livingston Ridge surface east of the indicated dissolution front in the Rustler," thus providing geographic bounds for the area of karstic processes in evaporites. This geographic constraint will be discussed further, together with the processes themselves, in a subsequent report.

This report is important to evaluating the longterm suitability of the WIPP in that it emphasizes the significance of conditions in the paleoclimate, paleohydrology, and paleodissolution that are quite different from presently observable conditions. These geological extremes over several thousand years can complicate interpretations of data representative of the present; one such set of interpretations has been specifically requested by the New Mexico Environmental Evaluation Group: the "water-balance study" (cf USDOE, 1983).

Finally, this report directly addresses another concern of the Environmental Evaluation Group: "drill a shallow auger-hole in the depression in the SW corner [of Sec. 29, T22S, R31E] in Zone III to address the suspicion of this depression being a doline" (cf USDOE, 1983).

Steven J. Lambert

Sandia National Laboratories 


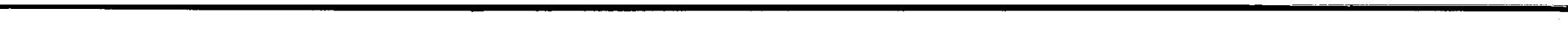




\section{Assessment of Near-Surface Dissolution At and Near the Waste Isolation Pilot Plant (WIPP), Southeastern New Mexico}

\section{Introduction}

The Waste Isolation Pilot Plant (WIPP) is a facility being developed by the US Department of Energy (DOE) for burying radioactive waste in underground beds of salt in Eddy County, NM. Although the proposed facility is more than $2000 \mathrm{ft}(615 \mathrm{~m})$ below the surface, there is continuing concern for the stability of rock adjacent to the host beds.

Strata overlying the WIPP facility horizon include sandstone, clay, and evaporites such as gypsum, anhydrite, and salt. If these evaporites are being actively dissolved in the subsurface, collapse sinks and related karst features should become apparent at places on the surface. Although no karst features have been definitely recognized on the surface closer than $\sim 3 \mathrm{mi}(4.8 \mathrm{~km})$ from the WIPP shaft, subsurface dissolution has been interpreted as present at and near the site from a recent gravity survey (Barrows and others, 1983).

The present study applying standard geologic techniques was undertaken to determine if active subsurface dissolution of evaporite beds is a plausible process in the modern geologic setting at the WIPP site. This study included examining available borehole data and surface features in the WIPP area. Other data, such as existing geologic maps, were examined and interpreted. Data from all these sources were used to construct the isopach maps and diagrams accompanying this report. These observations provided information for outlining the physiographic history of the modern terrain. Consideration of that history is essential to understanding the natural setting of the WIPP site.

\section{Physiography}

The WIPP site, located $\sim 25 \mathrm{mi}(40.2 \mathrm{~km})$ east of Carlsbad, Eddy County, NM (Figure 1), is situated on an unnamed physiographic surface that we call the Livingston Ridge surface for purposes of this discus- sion. The surface is underlain by caliche and windblown sand. Mesquite, shinnery oak, creosote bush, and associated flora of the Chihuahuan Desert characterize this semiarid region. The major physiographic features that have been a part of the recent geologic history of the area include Nash Draw, the Livingston Ridge surface, and The Divide. The Pecos River, whose modern course lies $\sim 20 \mathrm{mi}(32 \mathrm{~km})$ west of the WIPP site, has been a major influence in the physiographic history of the region.

Nash Draw is the most distinctive topographic feature at or near the WIPP site. A northeasterly trending depression $\sim 19 \mathrm{mi}(30.6 \mathrm{~km})$ long, it ranges from $\sim 5 \mathrm{mi}(8 \mathrm{~km})$ wide in its central portion to $\sim 10$ $\mathrm{mi}(16.1 \mathrm{~km})$ wide in its northern portion. The greater width in the north results from erosional dissection that bifurcates the drainage system into a northwestern and a northeastern lobe. Nash Draw is bounded on the west by Quahada Ridge and on the east by Livingston Ridge. Along its north rim the Maroon Cliffs form a barrier between Nash Draw and Clayton Basin.

The Livingston Ridge surface stretches eastward from Nash Draw 12 to $13 \mathrm{mi}(19.3$ to $20.9 \mathrm{~km})$ to Antelope Ridge, which lies along the western edge of San Simon Swale (Figure 1). The surface is a rolling, featureless plain.

Windblown sand has accumulated over much of the Livingston Ridge surface and in parts of Nash Draw and San Simon Swale. Some active dunes are present in the Los Medaños area on the southern part of the Livingston Ridge surface. Active dunes are also present locally at other places, but most of the windblown sand is in the form of stabilized coppice dunes-accumulations of sand around mesquite and other plants. The active dunes take the form of incipient crescent-shaped barchans or elongate transverse dunes. Closed depressions called "blowouts" are common features within both stabilized and active dune areas. 




Figure 1. Index map showing major features discussed in this report

The Divide is the proper name for a low hill rising above the Livingston Ridge surface and separating surface drainage towards Nash Draw on the west and San Simon Swale on the east. Much of the drainage around The Divide is now masked by windblown sand; visible drainage is intermittent and discontinuous. The entire area of the Livingston Ridge surface and The Divide has been a stable area of low relief for at least the past 500,000 yr (Bachman, 1980). Previously, westerly trending ridges and intervening swales with through-flowing streams radiated from the general area of The Divide. Gradients were low, with streams of low to moderate energy.

\section{Geology}

The geology of the WIPP site has been discussed extensively in the literature (Jones, 1973 and 1978; Bachman, 1980 and 1984; Lambert, 1983; Mercer, 1983; Borns and others, 1983). Only factors pertinent to a discussion of late geologic history and to the problem of dissolution will be treated here. 


\section{Stratigraphy}

The stratigraphy of the WIPP site has been discussed previously in detail (Jones, 1973 and 1978; Mercer, 1983; Lambert, 1983) and is presented only in outline here. Rocks in the stratigraphic column bearing on the present study are Permian, Triassic, Tertiary, and Quaternary in age. Permian rocks include four formations of the Ochoan series. In ascending order, these are the Castile, Salado, and Rustler Formations and the Dewey Lake Red Beds. They are overlain unconformably by clastic sediments of Triassic age. Surface and near-surface rocks include the Ogallala Formation and a variety of surficial deposits (Table 1).

Castile and Salado rocks are very soluble and are represented by dissolution breccia where they occur at the surface $\sim 25 \mathrm{mi}(40 \mathrm{~km})$ southwest of the WIPP site. At the WIPP site both these units are deeply buried and apparently have not been exposed to dissolution. Of the stratigraphic units close to the surface at and near the WIPP site, anhydrite, gypsum, and salt in the Rustler Formation in the subsurface are the most susceptible to dissolution resulting in karst features at the surface.

In addition to these evaporites, the Rustler includes the water-bearing Culebra and Magenta Dolomite Members. The water in these members is usually confined to the individual members where these are within an impermeable sequence of anhydrite or gypsum. Where the Rustler is exposed in Nash Draw, the dolomite members are fractured and the gypsum beds are disrupted by many collapse sinks and caves as a result of local dissolution. At places in the subsurface underlying the Livingston Ridge surface, boreholes have encountered cavernous intervals and clayey residuum at horizons where salt and gypsum are present normally in more complete stratigraphic sections.

The quality of the water in the dolomite members has been discussed in detail by Mercer (1983). Qualities vary widely over the region and are classified as saline to briny. "Dissolved solids in waters associated with the Culebra Dolomite Member range in concen- tration from 3,200 milligrams per liter. . .to 420,000 milligrams per liter" in test holes at and near the WIPP site (Mercer, 1983, p 62). "Dissolved solids in water associated with the Magenta Dolomite Member. . range in concentration from 5,460 milligrams per liter. ..to 270,000 milligrams per liter" (Mercer, $1983, p 68)$. Both waters are capable of dissolving more solids. Saturated brine occurs in a clayey brecciated unit at the basal contact of the Rustler with the Salado Formation in the subsurface in Nash Draw.

The Rustler Formation varies in thickness from $263 \mathrm{ft}(80.2 \mathrm{~m})$ in the subsurface in Nash Draw (Borehole WIPP-27) to $460 \mathrm{ft}(140.2 \mathrm{~m})$ near the southeastern edge of the site (Borehole P-18). The thinning of the formation in Nash Draw is attributable to dissolution of evaporite beds in the formation. Thinning of the formation beneath the Livingston Ridge surface is attributed both to dissolution of salt within the formation and to variations of thickness during original deposition (Jones, 1973, p 23; Mercer, 1983, p 45). Figure 2 shows some of the variations.

The regional dip of rocks at the WIPP site is easterly $\sim 75$ to $100 \mathrm{ft} / \mathrm{mi}(14$ to $18 \mathrm{~m} / \mathrm{km})$. Owing to this regional dip, rock units are more deeply buried from west to east. Thus the Rustler Formation is exposed at the surface in Nash Draw. At Livingston Ridge along the eastern edge of Nash Draw, the Rustler is buried beneath Dewey Lake Red Beds to a depth of 200 to $300 \mathrm{ft}(61$ to $91 \mathrm{~m})$. At the WIPP site the Rustler is beneath 300 to $400 \mathrm{ft}$ (91 to $122 \mathrm{~m}$ ) of Dewey Lake Red Beds. At and near The Divide the Rustler is covered by $>500 \mathrm{ft}(152 \mathrm{~m})$ of Dewey Lake Red Beds and 200 to $300 \mathrm{ft}$ (61 to $91 \mathrm{~m}$ ) of Triassic rocks.

Rocks of both the Dewey Lake Red Beds and Triassic are composed of insoluble clastic rocks. Karst features cannot be expected to develop in these units unless there has been extensive dissolution in underlying formations. Although veinlets and pods of selenite at many places in the Dewey Lake Red Beds indicate circulation of sulfate-bearing waters in this unit in the past, the Dewey Lake at present "has not normally been found to yield water to wells" (Mercer, 1983, p 70). 
Table 1. Summary of Stratigraphic Units Discussed in This Report At and Near the WIPP Site

\begin{tabular}{lllll} 
System & Series & Formation & Thickness (ft) & Characteristics \\
\hline Quaternary & Recent & $\begin{array}{l}\text { Windblown sand } \\
\text { Alluvium } \\
\text { Playa deposits }\end{array}$ & $\begin{array}{l}0 \text { to } 30 \\
0 \text { to } 20\end{array}$ & $\begin{array}{l}\text { Sand dunes } \\
\text { Arroyo deposits } \\
\text { Pilt and clay in closed basins }\end{array}$ \\
& $\begin{array}{l}\text { Spring deposits } \\
\text { Pleistocene }\end{array}$ & 0 to 30 & $\begin{array}{l}\text { Gypsite spring mounds and } \\
\text { runoff deposits }\end{array}$ \\
& Berino soil & 0 to 4 & $\begin{array}{l}\text { Dark reddish, clayey, non- } \\
\text { calcareous paleosol } \\
\text { White ledge-forming caliche } \\
\end{array}$ \\
& $\begin{array}{l}\text { Mescalero caliche } \\
\text { Gatuña Formation }\end{array}$ & $\begin{array}{l}0 \text { to } 10 \\
0 \text { to } 70+\end{array}$ & $\begin{array}{l}\text { Dark reddish-brown to } \\
\text { yellowish-brown gravel, sand, } \\
\text { silt }\end{array}$ \\
& & &
\end{tabular}

Tertiary $\begin{aligned} & \text { Miocene- } \\ & \text { Pliocene }\end{aligned} \quad$ Ogallala Formation 0 to 26+

Gray to yellowish-gray sand and gravel, capped by distinctive pisolitic caliche. Preserved at The Divide and Grama Ridge

\begin{tabular}{|c|c|c|c|c|}
\hline Triassic & & $\begin{array}{l}\text { Dockum group, } \\
\text { undivided }\end{array}$ & 0 to $300+$ & $\begin{array}{l}\text { Reddish-brown to gray, coarse } \\
\text { sandstone and conglomerate }\end{array}$ \\
\hline \multirow[t]{4}{*}{ Permian } & Ochoan & Dewey Lake Red Beds & 150 to 550 & $\begin{array}{l}\text { Reddish-brown fine-grained sand- } \\
\text { stone. Many greenish-gray } \\
\text { reduction spots }\end{array}$ \\
\hline & & Rustler Formation & 300 to $450+$ & $\begin{array}{l}\text { Gypsum, anhydrite, salt, and dolo- } \\
\text { mite. (Includes the Culebra Dolo- } \\
\text { mite Member near the middle } \\
\text { and the Magenta Dolomite } \\
\text { Member in the upper part.) }\end{array}$ \\
\hline & & Salado Formation & 1800 to 2000 & $\begin{array}{l}\text { Salt, potash minerals, and minor } \\
\text { beds of gypsum and clay. Beds in } \\
\text { this formation are being } \\
\text { examined as potential host rocks } \\
\text { for emplacing radioactive waste }\end{array}$ \\
\hline & & Castile Formation & \pm 2000 & $\begin{array}{l}\text { Anhydrite and gypsum with inter- } \\
\text { beds of salt }\end{array}$ \\
\hline
\end{tabular}




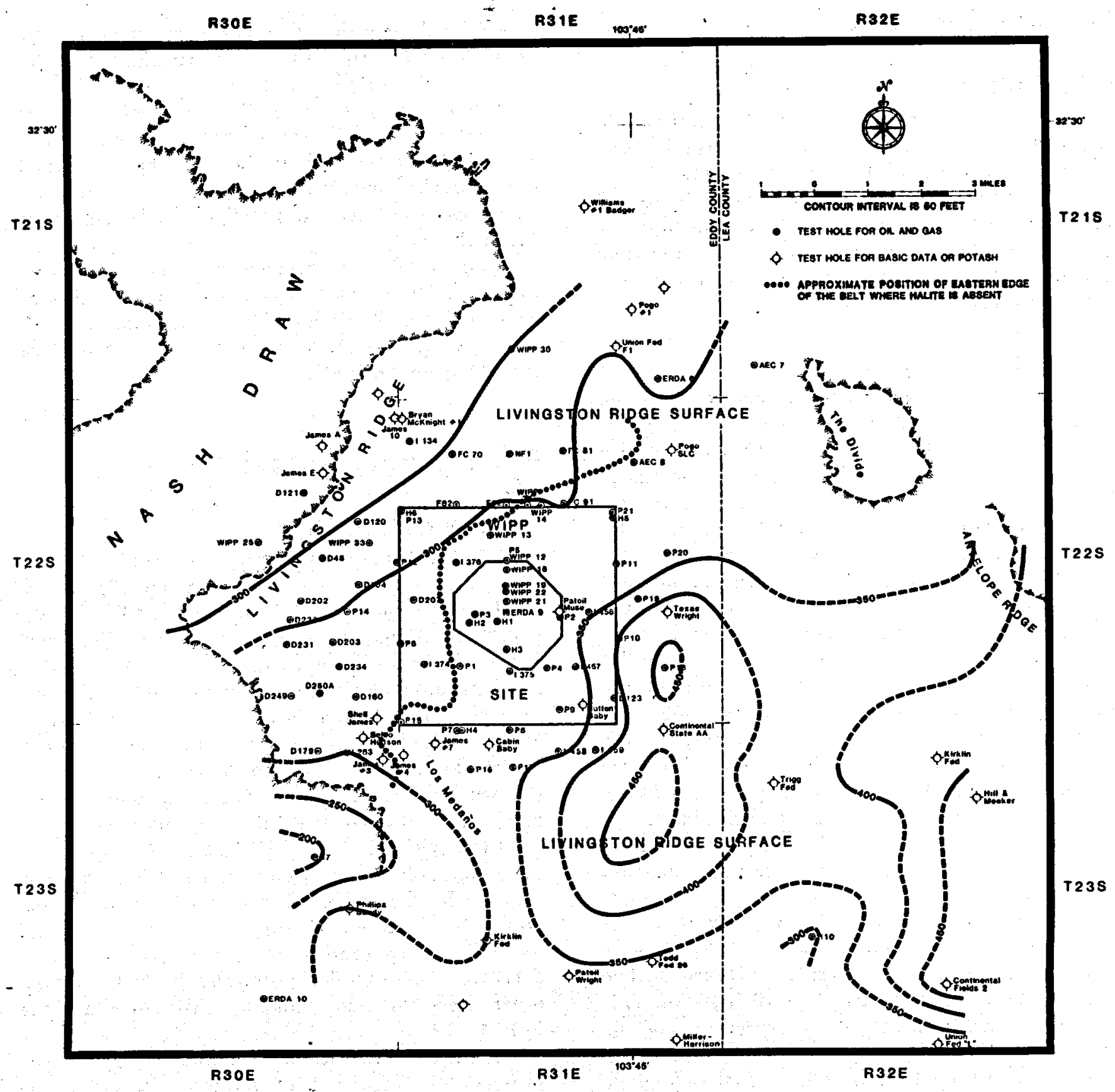

Figure 2. Isopach map of Rustler Formation 


\section{Tertiary Deposits}

\section{Introduction}

Although there are many gaps in the stratigraphic record, rocks of Tertiary and Quaternary age preserve the latest geologic history of southeastern New Mexico. A particularly long gap occurs in the record through early Tertiary time, and the physiography of the region at that time can only be conjectured. The region was above sea level; presumably erosion was the dominant process.

\section{Ogallala Formation}

The Ogallala Formation of Miocene and Pliocene age underlying the High Plains from Nebraska southward to western Texas and eastern New Mexico reflects a period of uplift and erosion of the Rocky Mountains. This formation was deposited mostly as a complex sequence of alluvial fans on an irregular erosion surface by streams flowing toward the south and east from the young mountains. In southeastern New Mexico extensive deposits of windblown sand characterize the interstream deposits of the Ogallala. Although the Ogallala Formation is now a remnant of a major depositional cycle in the past, it represents the first stage in developing the modern landscape.

At the termination of Ogallala deposition the region was unusually stable. A thick pedogenic caliche that accumulated on the surface is preserved as the well-known caliche "caprock" of the High Plains. The caprock is a complex deposit formed during at least 3 million years of desiccation, brecciation, and recementation.

The Ogallala Formation is as much as $400 \mathrm{ft}$ $(122 \mathrm{~m})$ thick at places in southeastern New Mexico. A thin remnant $26 \mathrm{ft}(8 \mathrm{~m})$ thick is preserved at The Divide $\sim 6 \mathrm{mi}(9.6 \mathrm{~km})$ east of the WIPP site. This remnant is significant to the interpretation of the physiographic history of the region. It may represent a western depositional wedge-edge of the Ogallala across a relatively high surface. Examination of the isopach maps accompanying this report suggests that the general area of The Divide was a positive topographic feature as long ago as Ogallala time.

Regional drainage during Ogallala time was towards the south and the southeast, but details of the drainage system at or near the WIPP site are not clear because extensive deposits of the formation are not available for analysis. It is probable that an ancestral Pecos River flowed southward in New Mexico along a course within 3 to $10 \mathrm{mi}$ ( 5 to $16 \mathrm{~km}$ ) east of its present channel. Thick deposits of alluvial fill to the south in Texas may be, in part, the result of this drainage and depositional episode. These alluvial deposits are $>1500 \mathrm{ft}(460 \mathrm{~m}$ ) thick (Maley and Huffington, 1953). They were deposited in basins formed by subsidence, or collapse, as a result of dissolution of salt from formations in the subsurface. The older parts of these deposits are present only in the subsurface, and their presence is known only from exploratory boreholes for oil and gas. Evidence is not available to determine the age of these deposits.

Major changes in drainage occurred later in Pleistocene time when some secondary drainages flowing westward from the High Plains were developed. These drainage systems flowed into the ancestral Pecos River (Bachman, 1984).

\section{Pleistocene Deposits}

\section{Gatuña Formation}

The Gatuña Formation is at least as old as Middle Pleistocene and may contain some much older deposits. Characteristically it consists of reddish-brown, poorly consolidated sand, gravel, and silty clay. Deposits that are assigned to the Gatuna Formation are distributed along the east side of the Pecos River in Nash Draw, Clayton Basin, and east of Artesia and Hagerman, NM $\sim 30$ to $50 \mathrm{mi}(48$ to $80 \mathrm{~km}$ ) north of Carlsbad (Bachman, 1976). In Pierce Canyon $\sim 20 \mathrm{mi}$ (32 km) southeast of Carlsbad it includes stream gravels that have collapsed into ancient sinks.

In the vicinity of the WIPP site, the Gatuña rests unconformably on the Dewey Lake Red Beds. It is overlain by the pedogenic Mescalero caliche, which accumulated on stable surfaces following Gatuña deposition. The presence of the Mescalero caliche overlying the formation separates the Gatuña from other deposits and aids in distinguishing the formation.

The age of the Gatuna Formation is based on the presence of a thin bed of volcanic ash within the formation on the east side of Nash Draw. The ash has been identified as a member of the Pearlette family of ash falls, the "Lava Creek B ash" (Izett and Wilcox, 1982). It was derived from the Yellowstone area, WY between 500,000 and 600,000 yr ago. The Mescalero caliche overlying the Gatuna confirms this age. It began to form $\sim 500,000 \mathrm{yr}$ ago (Bachman, 1980).

Near Artesia and Hagerman and in Gatuña Canyon to the north of the WIPP site, gravels in the Gatuna Formation indicate that they were deposited by westward-flowing streams. Carbonate pebbles in the gravels contain unique spherical or ovoidal accretionary masses (pisoliths) derived from the High 
Plains caprock to the east. These distinctive accretionary masses are characteristic of the High Plains caprock and cannot be confused with other rocks in the region. Additional evidence for westward-flowing streams during Gatuña time is provided by distinctive quartzite pebbles derived from Triassic beds exposed to the east of the present Pecos River. It is assumed that these westward-flowing streams emptied into the ancestral Pecos River.

During the present study, the Gatuna Formation was examined and measured at many places along Livingston Ridge on the east side of Nash Draw. Gravels deposited by westward-flowing streams are exposed at several localities. These include crossbedded, poorly sorted deposits in channels, which indicates deposition by water flowing at moderate velocity (Figure 3). The measured thicknesses of the Gatuña along Livingston Ridge, and borehole data, were used to construct the isopach map accompanying this report (Figure 4).

The isopach map of the Gatuna Formation indicates the presence of an east-west channel north of the WIPP site during Gatuna time. Sediments $>70 \mathrm{ft}$ (21 m) thick were deposited there. An east-west ridge was present across the northern part of the site, and an area of low relief received sediments across the central and southern parts of the site. Comparison of the Gatuna isopach map with the isopach map of Triassic rocks (Figure 5) indicates that the Gatuña channel and the lowland south of the site drained and eroded the Triassic rocks exposed at the surface. Gatuna streams flowed across both Triassic and Dewey Lake Red Beds strata (Figure 6).

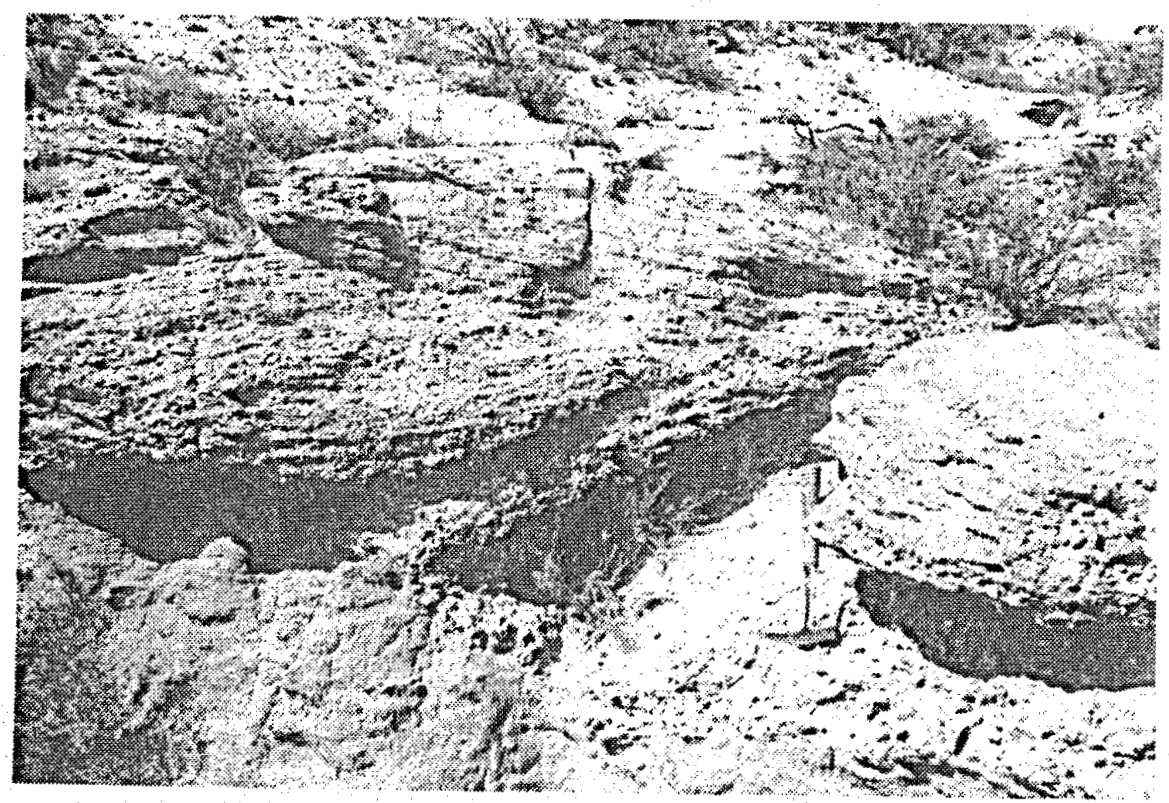

Figure 3. Cross-bedded pebble conglomerate in channel deposit at base of Gatuña Formation (SW1/4 NW1/4 Sec. 1, T22S, R30E). (The Gatuña rests on Dewey Lake Red Beds at this locality.) 


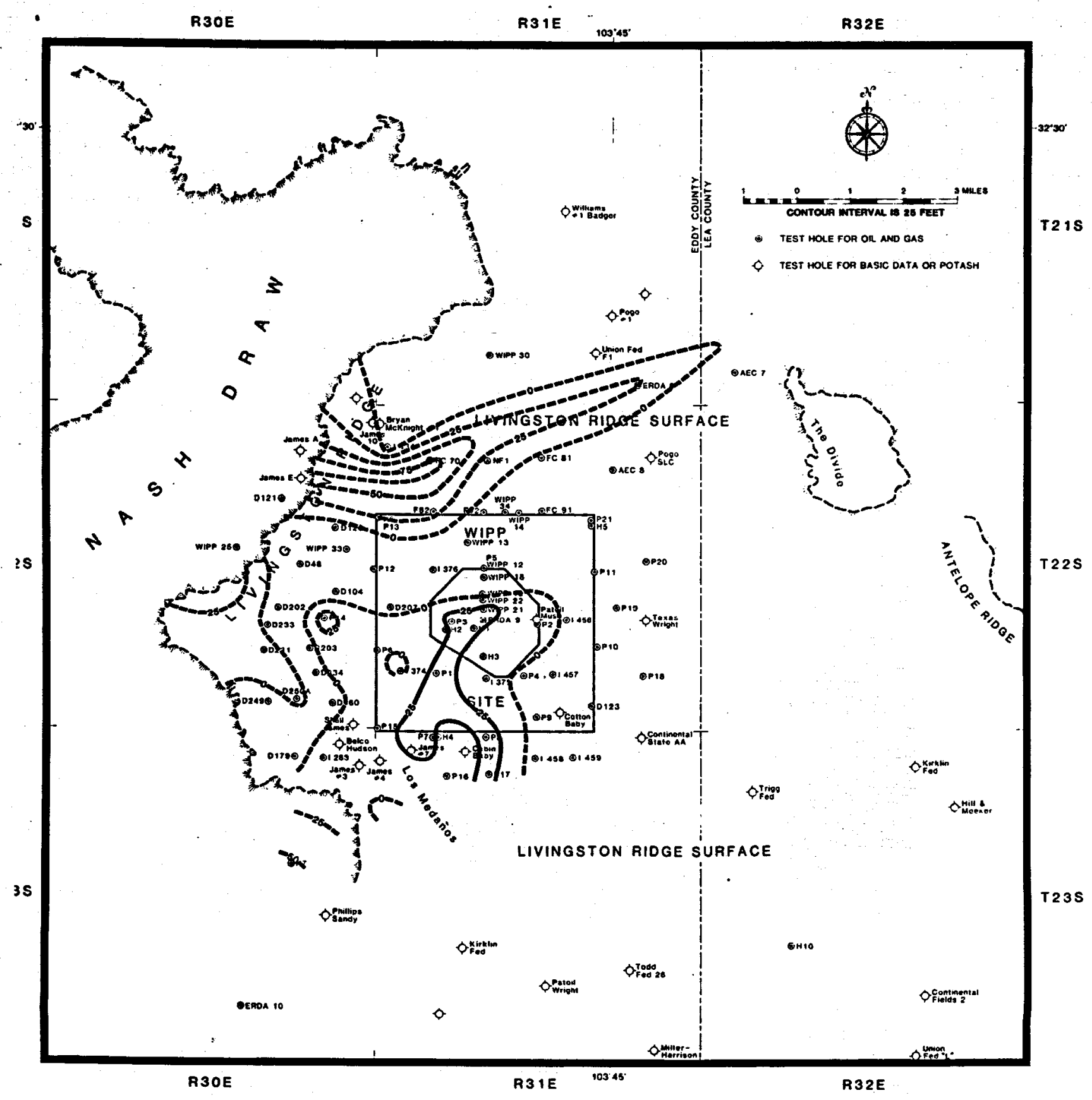

Figure 4. Isopach map of Gatuña Formation 


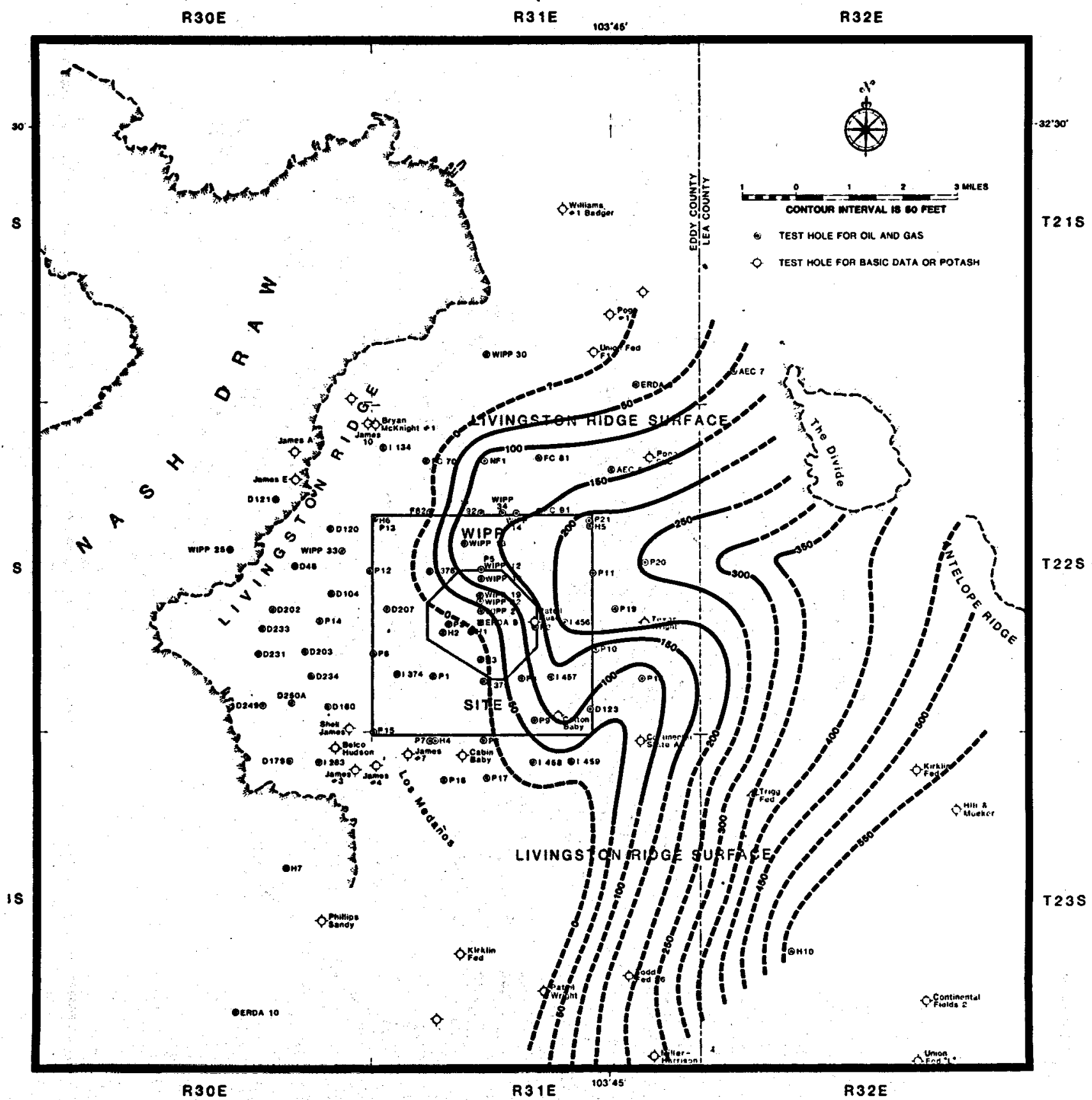

Figure 5. Isopach map of Triassic rocks 


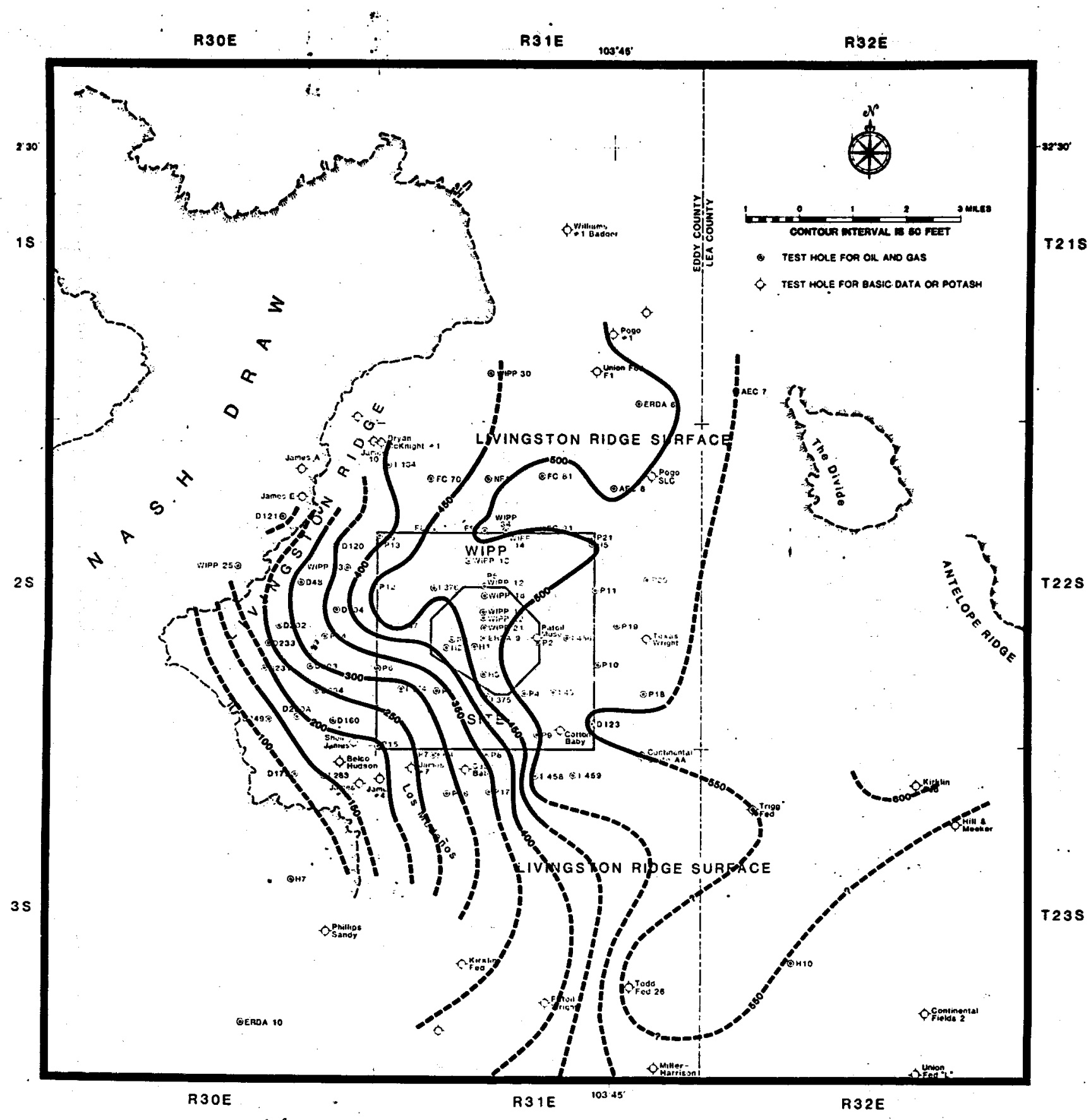

Figure 6. Isopach map of Dewey Lake Red Beds 


\section{Mescalero Caliche}

The term "caliche" has been applied to many kinds of carbonate and sulfate deposits. As used in this report, "caliche" refers to a deposit of calcium carbonate (a calcrete) displaying a distinctive, predictable morphology. The morphology indicates formation of the caliche by soil processes. By examining caliche profiles through their evolutionary development over broad regions, we find it possible to determine their evolutionary stage and even to estimate their age in relative terms (Bachman and Machette, 1977).

Soil formation is a relatively slow process requiring a stable surface for development. Soils do not mature on constantly eroding surfaces or surfaces disrupted by subsidence, collapse, or persistent tectonic adjustment. Extensive soil development should not be expected at places where specific karst processes are extremely active. Soil classes depend on the nature of parent material, the amount of rainfall, the temperature, and the absence or presence of organic material. Soils may change character or may even be destroyed by radical changes in climate. For these reasons soils are a valuable tool for estimating the duration of stability of a geomorphic surface and the persistence of a climatic regime.

Pedogenic caliche, such as the Mescalero caliche, is deposited on an aggrading eolian surface. The calcium carbonate comprising the caliche profile is derived from wind-borne sand and dust as well as from rainwater. Dust in the Southwest often contains as much as $1.3 \%$ to $5.7 \%$ calcium carbonate (Gile and others, 1981, p 63). Rainwater may contain $>4 \mathrm{mg}$ of calcium carbonate/L (Junge and Werby, 1958). The calcium carbonate is leached from the wind-borne sediments in minute seasonal increments, is carried downward by percolating soil moisture, and is then deposited in a zone of evaporation in underlying soil horizons. The zone of evaporation represents the aver-: age depth of penetration of infiltration of soil moisture over the period of deposition.

In southern New Mexico, four stages of evolutionary development of pedogenic caliche are recognized (Gile and others, 1966). Over broader regions this evolution has been further refined into six stages (Bachman and Machette, 1977). These six morphologic stages are related to the relative age of the deposit, according to the availability of a continuing supply of calcium carbonate. The stages are visible to the naked eye and are defined in general terms as follows:

\section{Stage : Definition}

I Carbonate is in form of filamentous or (Youngest) faint coatings on detrital grains. Coatings may be restricted to the underside of individual grains.

II

III In addition to coating detrital grains, carbonate occurs as nodules as well as forming a friable or disseminated matrix. The horizon is plugged to the downward movement of solutions.

IV Carbonate is platy and firmly cements the matrix. The horizon is plugged to downward-moving solutions.

V Carbonate is platy to tabular and very strongly cemented. A well-developed laminar layer occurs on the upper surface. The laminar layer forms because calcium carbonate-bearing water can no longer penetrate the horizon.

VI The carbonate is massive, multilaminar, (Oldest) and strongly cemented. Includes abundant pisoliths. The upper surface may be brecciated. The Ogallala "caprock" is an example of this stage.

The Mescalero caliche was an ancient soil horizon now outcropping as ledges of light gray to white, platy to tabular, dense, sandy calcium carbonate as much as $10 \mathrm{ft}(3 \mathrm{~m})$ thick. It was named for the Mescalero geomorphic surface and the Mescalero sands east of Roswell, NM (Bachman, 1976) $\sim 75 \mathrm{mi}(120 \mathrm{~km})$ north of the WIPP site. It rests on the Mescalero surface, which encompasses the Livingston Ridge surface of this report, from its type area east of the Pecos River southward at least to the New Mexico-Texas State line, a distance of $\sim 100 \mathrm{mi}(160 \mathrm{~km})$.

The Mescalero caliche is an example of Stage $V$ in the above classification. It engulfs the bedrock on which it rests (Figure 7) and forms a barrier to the infiltration of precipitation. Where the laminar horizon and the dense plugged horizons within the caliche are at the surface, they contribute to rapid runoff and even to flooding during periods of heavy rainfall. Hazardous flooding conditions have been observed in populated areas such as Las Vegas, NV (Lattman, 1973) where similar caliches are at, or near, the surface. 
The basal part of the Mescalero caliche began to form $\sim 510,000 \mathrm{yr}$ ago, as determined by measuring the disequilibrium of the uranuim series. The upper crust of the caliche began to form $\sim 410,000 \mathrm{yr}$ ago (Rosholt, written communication, 1979). The technique used in these determinations has been described by Szabo (1969) and Rosholt (1980).

In southern New Mexico, caliche morphologically similar to the Mescalero has been studied extensively. Both the organic and inorganic carbon fractions of the upper laminar layers there indicate C-14 dates ranging from 21,000 to 32,000 yr (Gile and others, 1981, $\mathrm{p}$ 122). This indicates only that the carbonate in this horizon is extremely mobile, and that the laminar horizon formed rapidly. It also suggests the large influence of a small proportion of recently precipitated carbonate on the C-14 age (Gile and others, 1981, pp 76-77).

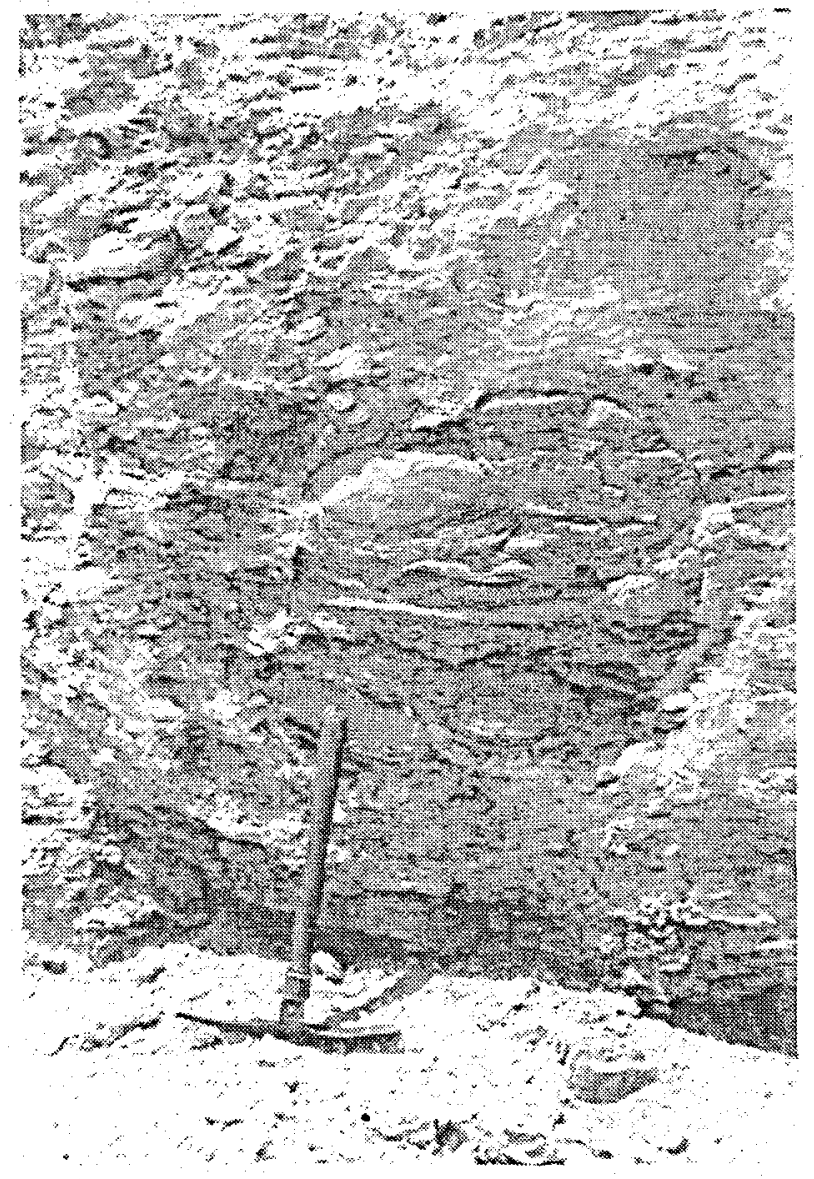

Figure 7. Mescalero caliche engulfing Triassic rocks (SE $1 / 4$ $\mathrm{SE}^{1}+$ Sec. 23, T22S, R31E). (Mescalero-Triassic contact is the sharp boundary just above the head of the trenching tool. The handle of the trenching tool points upward to a rounded "boulder" of Triassic sandstone surrounded by caliche.)

\section{Berino Soil}

The Berino soil is a dark-red, sandy, clayey, noncalcareous paleosol overlying the Mescalero caliche near the WIPP site. Rarely more than $3 \mathrm{ft}(1 \mathrm{~m})$ thick, it is usually overlain by windblown sand and is observed mainly in road cuts and at construction sites.

In southeastern New Mexico, deposits such as the Mescalero caliche and the overlying windblown sand that are adjacent to the Berino soil are very calcareous. That the Berino is noncalcareous indicates leaching of the carbonates from this unit. The Berino is probably a remnant of an ancient soil sequence, the argillic $B$ horizon, which included the Mescalero caliche at its base as the $\mathrm{C}$ or $\mathrm{K}$ soil horizon.

Uranium-series disequilibrium studies indicate that the Berino began to form $\sim 350,000 \mathrm{yr}$ ago (Rosholt, written communication, 1979). This age does not coincide with the youngest age of the Mescalero, which is one reason for considering the Berino as a remnant of a former more extensive sequence of soils. Further, it is also inconceivable that the leaching of a $\mathrm{B}$ horizon as thin as the Berino as now preserved could have yielded the amount of carbonate required to form the underlying Mescalero. Like the Mescalero caliche, formation of the Berino soil depended on a relatively long period of tectonic and geomorphic stability within a limited climatic regime.

\section{Spring Deposits}

Soft, earthy, white deposits of calcium sulfate (gypsite) resulting from ancient spring activity in a zone roughly parallel to Livingston Ridge occur along the east side of Nash Draw. At least six low spring mounds are situated along the crest of a low anticline in Dewey Lake Red Beds (NE $1 / 4$ Sec. 15, T22S, R30E) where tension fractures allowed seepage of sulfatebearing water to the surface.

Although the regional dip of the bedrock is toward the east, dissolution of underlying evaporites in the Rustler Formation in Nash Draw has resulted in local collapse and flexures toward the west. This dissolution and collapse of strata is presumed as the cause of the local anticline in the Dewey Lake Red Beds. The mounds developed as spring water evaporated. Windborne dust settling to the moist ground added to the accumulation. At times the spring-fed water flowed westward over the surface as far as $1 / 2 \mathrm{mi}(0.8 \mathrm{~km})$ downslope towards the center of Nash Draw.

Snails and bones of extinct species of horses and camels have been found in these spring deposits. The bones indicate active springs during Late Pleistocene time, after deposition of the Mescalero caliche (Bachman, 1980). Although long extinct, these springs indicate that in the past gypsum and associated salts 
dissolved locally in the subsurface and were then brought to the surface by circulating groundwater.

There is a major hiatus between the spring deposits (>25,000 yr; J. N. Rosholt, written communication, 1979) and the Berino soil; this part of later Pleistocene time is apparently not represented in the sediments of southeastern New Mexico.

\section{Playa Deposits}

Playa deposits consisting of silt, clay, and saline evaporites are preserved in the larger closed basins and in Salt Lake (Laguna Grande de la Sal) at the south end of Nash Draw. They are particularly well developed in Clayton Basin, where fossil snails are preserved in the deposits. However, playa deposits are not well represented in Nash Draw, where they would be if Nash Draw were a stable depression. Presumably Nash Draw was disrupted by much subsidence and the formation of collapse sinks. Water drains readily into these sinks without collecting on the surface as intermittent ponds, necessary for accumulating playa deposits.

At places within dune fields on the Livingston Ridge surface and elsewhere, incipient playas develop intermittently within blowouts. These are characterized by mud-cracked silt at the surface. Within some blowouts silty carbonates were deposited in thin, soft, light-gray lenticular beds.

\section{Alluvium}

Silt, sand, and gravel, which are deposited in depressions by running water, are especially thick (at least $20 \mathrm{ft}(6 \mathrm{~m}))$ in the northern part of Nash Draw. These deposits are presently eroding in conjunction with the formation of collapse sinks downstream in Nash Draw. The sinks increase the gradient of the arroyo systems, which in turn contributes to erosion and dissection.

Much alluvium is eroded from the surface and carried into karst sinks and tunnels by means of solution and fill (Lee, 1925). By this process solution cavities are rapidly filled and even "healed" by surficial debris. At some places deposits formed by this process are preserved as a chaotic mass of silt, sand, gravel, and blocks of gypsum.

\section{Windblown Sand}

Windblown sand is widespread at and near the WIPP site. Except for a small area of transverse dunes in the Los Medaños dune field south of the WIPP site, most dunes at and near the site are nondescript stabilized features, or at best may be classified as barchans or coppice dunes. Barchan dunes are crescent-shaped and have been observed only in areas of recent blowouts and active dune movement. They are most common in the Los Medaños field and in Bilbrey Basin east of the WIPP site. Coppice dunes are stabilized mounds of sand accumulating around shrubs such as mesquite or shinnery oak (Figure 8).

Blowouts (closed depressions within a dune field) are common in all types of dune fields in southeastern New Mexico and in the sand seas of the world. They develop where there is a lowering of the crest of a dune. "The local increase of wind velocity through the gap causes a rise in the rate of sand movement there, with a consequent removal of sand from the surface of the gap. The gap gets bigger and a blowout is formed" (Bagnold, 1973, p 206).

A blowout $\sim 1.4 \mathrm{mi}(2.3 \mathrm{~km})$ southwest of the WIPP shaft was examined in some detail to determine if this particular feature was related to karst processes. It is located in the SW1/4 SW1/4 Sec. 29, T22S, R31E and is $\sim 100 \mathrm{~m}$ west of Borehole P-1. The blowout, an elongate depression trending $N 60^{\circ} \mathrm{E}$, is $\sim 200 \mathrm{ft}(61 \mathrm{~m})$ long and $\sim 80 \mathrm{ft}(24 \mathrm{~m})$ wide. It is $6 \mathrm{ft}$ (1.8 $\mathrm{m}$ ) deep (Figure 9). Mud cracks form a weak pan in the bottom of the blowout (Figure 10). Coppice dunes rising above the depression on the leeward side probably formed as a result of wind action within the blowout (Figure 9). An auger hole in the bottom of the blowout reached the Mescalero caliche $0.8 \mathrm{~m}$ below the surface. A remnant of Berino soil is preserved in one side of the blowout.

There is no evidence of collapse of the Mescalero caliche or of other surficial deposits at this place because of karst processes. The stratigraphic section in Borehole P-1 is similar to that of the sections in other nearby boreholes. The halite in the upper part of the Rustler Formation dissolved at some time in the past but is present in the lower part of the Rustler. The Salado Formation appears to be intact.

Where blowouts are contained within a field of stabilized dunes, they may exist for a relatively long time in terms of the history of the dune field. On the Livingston Ridge surface the impermeable Mescalero caliche beneath the dunes holds water within blowouts during rainy seasons. The finest grained sediments are sorted by water and deposited on the surface of the depression. Upon drying, mud cracks form on the surface of these depressions and leave the impression of an ephemeral pool (Figure 10). . 


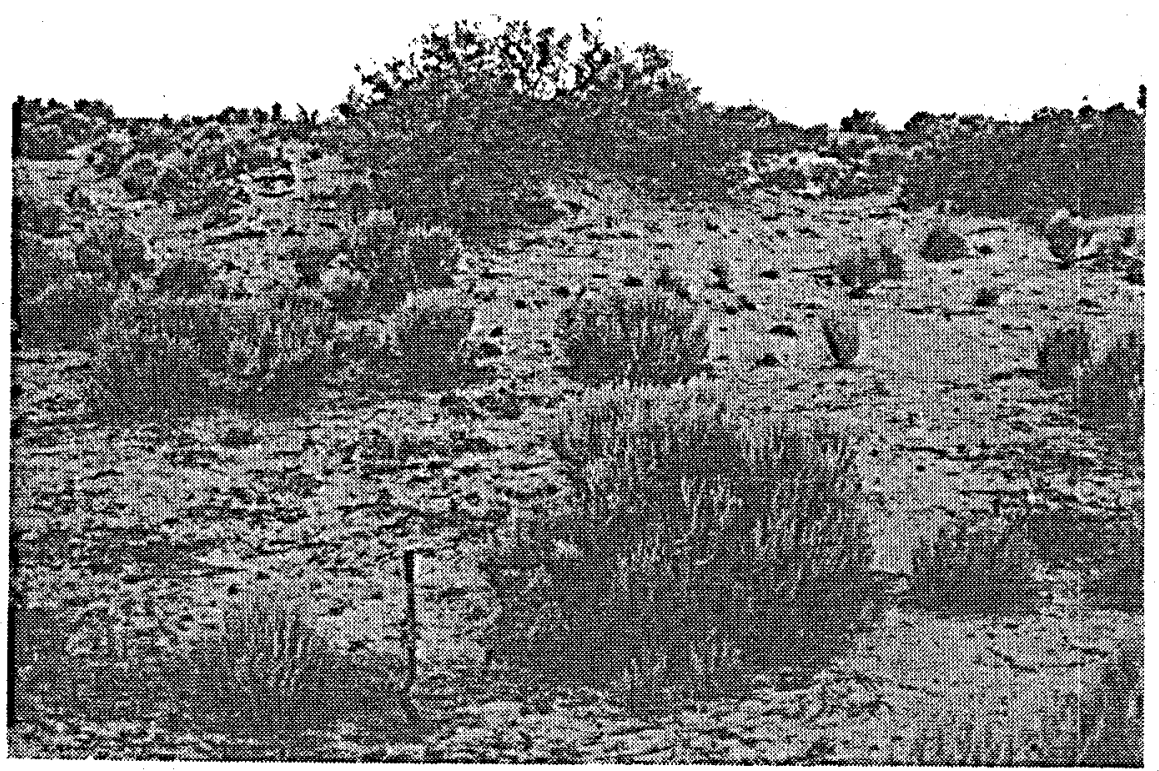

Figure 8. Coppice dune on skyline, on rim of blowout (SW $1 / 4 \mathrm{SW}^{1 / 4}$ Sec. 29 , T22S, R31E)

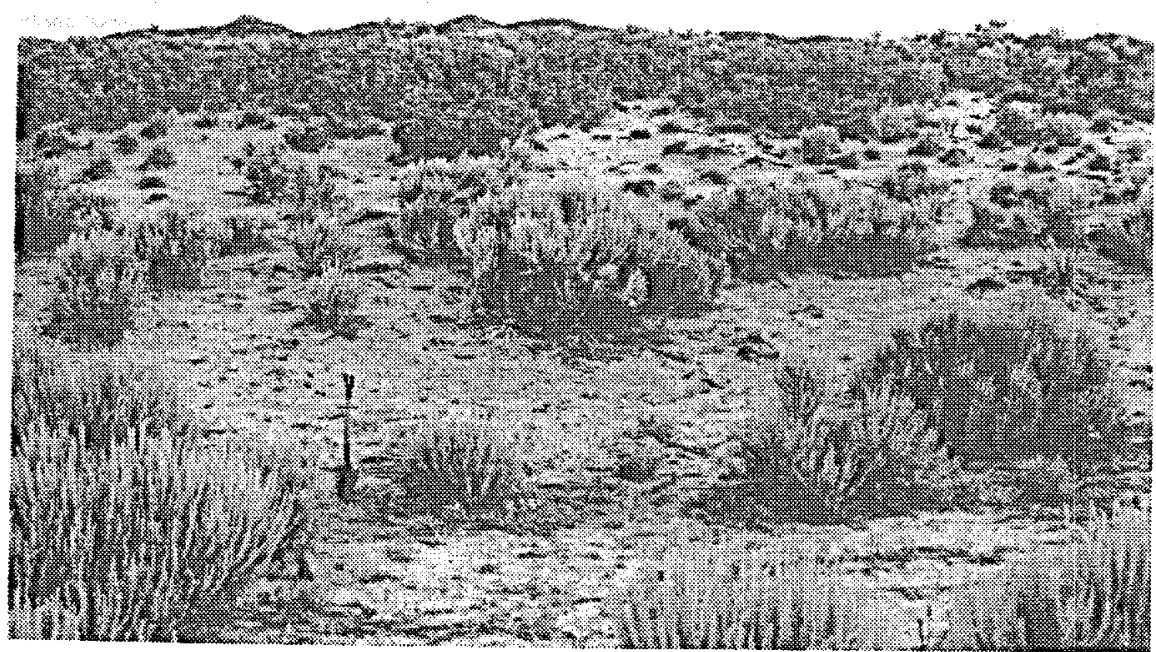

Figure 9. Blowout in dune sand (SW1/4 SW $1 / 4$ Sec. 29, T22S, R31E). (Coppice dunes are visible on the skyline.) 


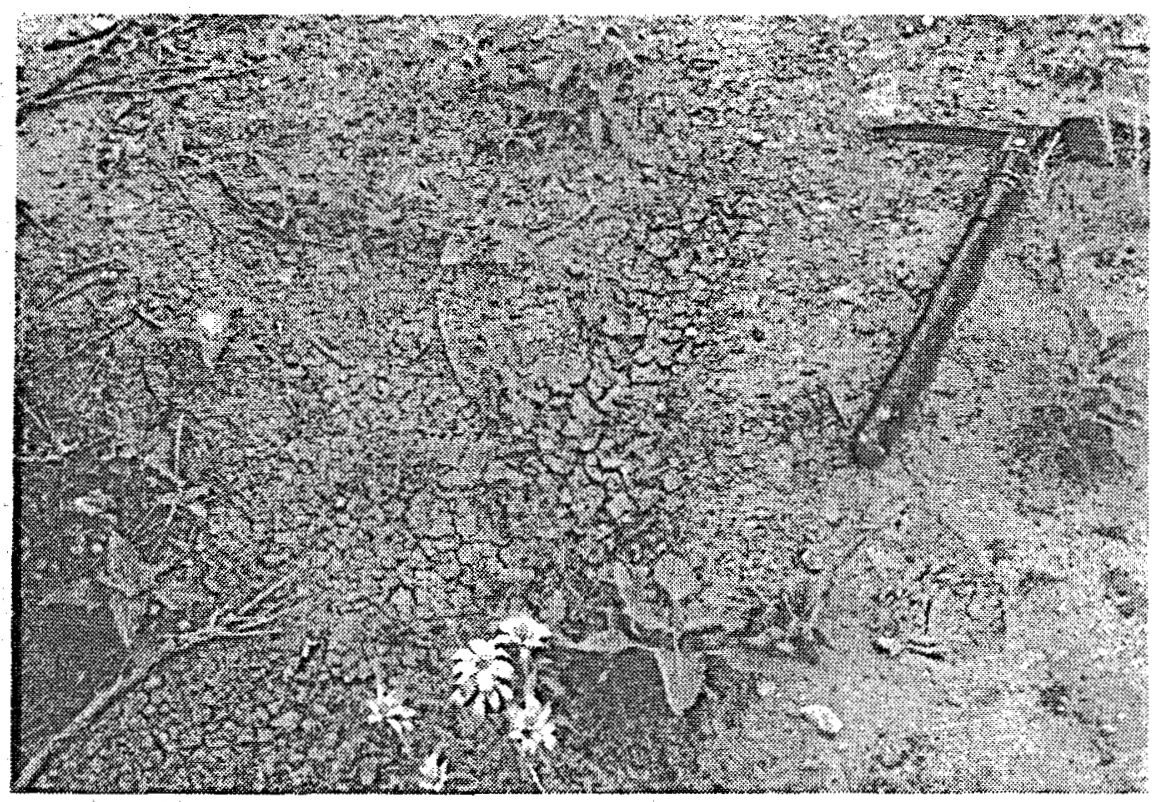

Figure 10. Mud-cracked pan in bottom of blowout (SW1/4 SW1/4 Sec. 29, T22S, R31E). (Water occasionally stands in blowouts after rain.)

\section{Karst and Near-Surface Dissolution}

The vast terminology of karst features and karst phenomena has been treated in compilations and glossaries in several languages. The most comprehensive of these in English is by Monroe (1970). His terminology emphasizes dissolution features in limestone (calcium carbonate) terrain. The process of dissolution in evaporites such as gypsum, halite, and related salts is dominantly the physical processes of dissolution and corrasion, in contrast to the chemical processes in limestone where $\mathrm{CO}_{2}$ in the atmosphere combines with water to form acids dissolving the carbonate. However, the terminology of karst in limestone generally applies to that in evaporites. Monroe's terminology is used here with minor modifications.

The term "karst" is applied here to a kind of topographic development in which the topography is formed chiefly by the dissolution of underlying rock. Such topography is commonly characterized by closed depressions, subterranean drainage, and caves. The closed depressions may be defined more specifically as dolines or collapse sinks. Dolines are basins or funnelshaped hollows "ranging in diameter from a few meters to a kilometer and in depth from a few to several hundred meters.... A distinction may be made between those formed by a direct solution of the. . surface zone, solution dolines, and those formed by collapse over a cave, collapse dolines" (Monroe, $1970, \mathrm{p} 7)$. The latter may also be termed "collapse sinks." The term "paleokarst" pertains to "a karstified rock or area that has been buried by later sediments" (Monroe, 1970, p 13).

Karst phenomena are common, and karst terrains and paleokarsts are common in southeastern New Mexico where Permian carbonates and evaporites are at, or near, the surface. Carlsbad Caverns and other caves in the Permian carbonate reef of the Guadalupe Mountains are the most widely known of these features. Less well-known is the terrain where evaporites have been dissolved to form complex karst landscape. Since dissolution of salt and gypsum is a recognized potential hazard to the WIPP site, a better understanding of the limits of this dissolution is paramount to understanding the geologic setting of the site.

Karst terminology should be defined with precision. Careless treatment of concepts of karst phenomena, and even carelessly using karst terminology, can 
contribute to misunderstanding and false impressions. The interpretation of karst activity in the vicinity of the WIPP site depends in part on understanding the distribution and physical nature of the stratigraphic units in the area. Although deep-seated dissolution has been active at localities around the periphery of the Delaware Basin in units associated with the Capitan Limestone and in the Pecos River drainage system overlying the Castile Formation (Lambert, 1983; Bachman, 1980 and 1984), deep-seated dissolution within the Delaware Basin is less probable because of physical limitations on the circulation of fresh water at depth. In contrast, dissolution of nearsurface evaporites is responsible for the visible karst features in Nash Draw and at other places at and near the WIPP site. The caves, collapse sinks, and spring deposits in Nash Draw indicate a relatively long geologic history of dissolution of gypsum and associated evaporites.

Stream gravels in the Gatuña Formation on both the east and west sides of Nash Draw indicate flowing streams across the area now encompassed by Nash Draw before it became a topographic depression (Figure 11). The Gatuna stream system eroded into the evaporites of the Rustler Formation, and collapse sinks began to form near the end of Gatuña time before the formation of the Mescalero caliche was well underway (Bachman, 1980). As a result of following the strike of the Rustler Formation for a time, Gatuna drainage contributed to coalescing these sinks. Thus, part of Nash Draw is a paleokarst feature. Paleokarst is prominent in Pierce Canyon $\sim 20 \mathrm{mi}(33 \mathrm{~km})$ south of the WIPP site.

In early studies of the WIPP site, dissolution of halite beds in the Rustler Formation was recognized over extensive areas beneath the Livingston Ridge surface (Jones, 1973). Halite beds are absent because of dissolution in the Rustler Formation in Nash Draw and along Livingston Ridge to the west of the site. They are absent in the Rustler above the Culebra Dolomite Member across the WIPP site itself (Mercer, 1983 , p 45, Figure 13). At many drillholes where the halite beds should be present, they are represented by intervals of reddish, clayey, insoluble residues. Dissolution of halite in the Rustler appears to be related to permeability changes in the Culebra (Mercer, 1983, p 60). Increased permeability in the Culebra allows unsaturated groundwater to access, and dissolve, the halite.

Dissolution of halite, hydration of anhydrite to gypsum, and dissolution of gypsum result in local changes in thickness, in fracturing, and in forming karst features in the Rustler Formation. Field evi- dence (Nash Draw as a topographic feature and ancient spring deposits) indicates such active processes for at least the latter half of Pleistocene time$\sim 500,000$ years.

Boreholes WIPP-33 and WIPP-14 were drilled on the Livingston Ridge surface specifically to address the problem of near-surface dissolution at and near the site (SAND80-2011; SAND82-1783). Information from these and other boreholes indicates that nearsurface dissolution is most likely in proximity to Nash Draw, where evaporates in the Rustler are relatively near the surface. The dissolution of halite beds in the Rustler indicates further that the dissolution front within the Rustler is directly related to proximity to Nash Draw. Eastiward from Nash Draw the front moves stratigraphically higher in the formation (Mercer, 1983, Figure 13). The easterly regional dip that plunges the Rustler deeper into the subsurface at and near the WIPP site is one factor that decreases the probability of near-surface dissolution at the site. The Dewey Lake Red Beds, which are composed of sandstone and silt, overlie the Rustler Formation at the site. These rocks do not dissolve readily, and water does not move through them freely. Karst features develop in these beds only if evaporites in the underlying Rustler are dissolved and the Dewey Lake collapses into the void.

WIPP-33 was drilled nearly $3 \mathrm{mi}$ west of the center of the WIPP site (SE $1 / 4$ Sec. 13, T22S, R30E) because of the presence at that locality of a small closed basin with unique characteristics. Preliminary tests by hand auger indicated more than $20 \mathrm{ft}(6 \mathrm{~m})$ of alluvial fill within the basin. In addition, the Mescalero caliche is disrupted along the rim of the basin. The Gatuna Formation is absent at that place. An arroyo $\sim 1 \mathrm{mi}(1.6 \mathrm{~km})$ long emptying into, and disappearing in, the basin is reminiscent of the conditions in the blind valley - a valley that ends suddenly where its stream disappears underground.

In the subsurface at WIPP-33 the Dewey Lake Red Beds are $357 \mathrm{ft}(110 \mathrm{~m})$ thick. This is an incomplete stratigraphic section that was eroded before the Mescalero caliche was deposited. The Rustler Formation, which is $276 \mathrm{ft}$ ( $84 \mathrm{~m})$ thick, is a diminutive section as compared with more complete sections where the Rustler may be as much as $450 \mathrm{ft}(137 \mathrm{~m})$ thick. This thinning of the Rustler at WIPP-33 may be attributed to dissolution of salt and gypsum; anhydrite has been hydrated to gypsum at this locality. Returns from drilling and a later video examination of the borehole indicated extensive cavities within the formation, straddling the gypsiferous Magenta dolomite member. 


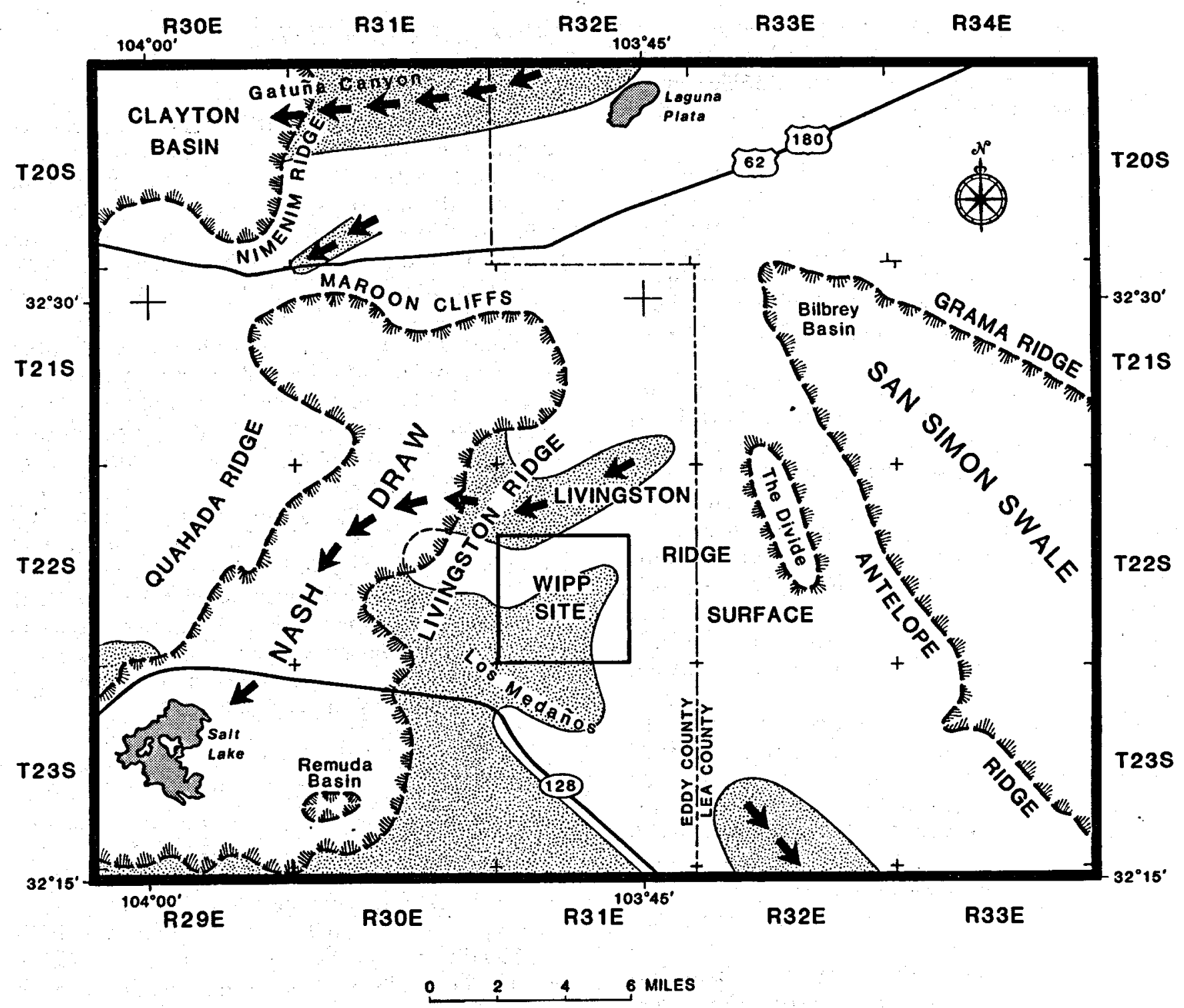

Flgure 11. Map showing distribution of Gatuña Formation (stippled) and probable course of streams during Gatuña time (arrows)

Borehole data from other localities at and near WIPP-33 indicate that salt and some gypsum have been dissolved from the Rustler in that area. Dissolution was particularly active in the Rustler in Nash Draw. These data are the basis for indicating an approximate position of the eastern edge of the belt where halite is absent from the Rustler Formation (Figure 2).

The spring deposits along the eastern edge of Nash Draw are presumed to be the result of this nearsurface dissolution. The presence of Late Pleistocene fossils in the spring deposits, and the fact that the springs are now extinct, indicate that the groundwater regime originally responsible for dissolving underground beds of gypsum and depositing spring deposits is no longer active. That activity was part of a paleokarst system resulting from a much different climatic regime. However, dissolution of the Rustler gypsum in Nash Draw began late in Gatuña time and is a continuing process.

WIPP-14 was drilled because of the presence of a pronounced gravity low suggesting a localized structural depression at that locality. The working hypothesis specified that the low density responsible for the gravity anomaly was due to dissolution of shallow 
beds, particularly in the Rustler Formation, in a manner analogous to that at the WIPP-33 locality (SAND82-1783, pp 2-5). A minor topographic depression is present at WIPP-14, but there is no evidence of collapse at the surface.

The Gatuna Formation is absent at WIPP-14 either because of nondeposition or because of preMescalero erosion. Triassic rocks are $\sim 126 \mathrm{ft}$ (39 m) thick; the Rustler is $313 \mathrm{ft}(96 \mathrm{~m})$ thick. Halite is absent in the Rustler above the Culebra Dolomite but is present in the lower part of the Rustler underlying the Culebra. Much of the calcium sulfate in the Rustler occurs as anhydrite.

The stratigraphic succession at WIPP-14 is comparable to that in other nearby drillholes. At Drillhole WIPP-34 $\sim 0.2 \mathrm{mi}(0.3 \mathrm{~km})$ west of WIPP-14, halite was not found above the Culebra Dolomite. Likewise, in other nearby drillholes (e.g., P-5, $\sim 1.2 \mathrm{mi}(2 \mathrm{~km})$ southwest of WIPP-14), halite is present in the Rustler only in the unit underlying the Culebra Dolomite. This indicates a regional distribution of halite that is not limited to the locality of WIPP-14. This pattern of distribution characterizes the central portion of the WIPP site, including the WIPP shaft itself (Borns and others, 1982, p 43).

Halite may have been present formerly in the upper part of the Rustler Formation in the vicinity of WIPP-14 and WIPP-34 but has been since removed by dissolution. Such dissolution was a regional intraformational process not confined to the point at which WIPP-14 was drilled. Therefore, the hypothesis that the low density responsible for the gravity anomaly at WIPP-14 was due to the local dissolution of shallow beds is untenable. The WIPP-14 locality is not analogous to the WIPP-33 locality. At WIPP-33 halite has been removed throughout the Rustler Formation. WIPP-33 is situated in a belt along the western border of the WIPP site parallel to Nash Draw where halite is completely absent from the Rustler (Figure 2).

Holt and Powers (1984) have suggested that the extent of dissolution around the WIPP shaft $\sim 2.1 \mathrm{mi}$ $(3.5 \mathrm{~km})$ southwest of WIPP-14 is less than previously reported. They have mapped the shaft in detail and report undisturbed depositional features in the zone originally believed to be dissolution residue (Jones, 1981). They state that "there is no disruption apparent which would be caused by volume reduction" (Holt and Powers, 1984, pp 4-11). This suggests that many structures in Rustler sediments may be explained as original depositional features. Rustler sedimentary facies and the environments of their deposition, as well as the concept of intraformational dissolution, should be reexamined in the light of this hypothesis.

\section{Discussion and Conclusions .}

No attempt is made here to explain the gravity anomalies described by Barrows and others (1983) at and near the WIPP site, the anomaly that resulted in drilling WIPP-14. However, anomalous gravity data from the WIPP site and east of the approximate position of the dissolution front in the Rustler Formation (Figure 2) are probably the result of factors other than near-surface dissolution.

True karst features should not be predicted on the Livingston Ridge surface east of the indicated dissolution front in the Rustler. The pattern of the isopach maps in this report (Figures 2 and 4) suggests that dissolution of halite in the Rustler, as indicated by Mercer (1983, Figure 13) north and east of WIPP-33, probably occurred during Gatuna time. The Rustler was then within the Gatuna drainage system and only partially protected by overlying beds. Gatuña deposits throughout southeastern New Mexico indicate that during the time of their deposition surface water was much more abundant that at any time since. Many of the results of dissolution observed today occurred during Gatuña time, more than 500,000 yr ago.

True karst surface features contain evidence of surface collapse, such as at the WIPP-33 locality, a topographic depression that is being actively filled by alluviation. Gypsum has been dissolved from the Rustler Formation in zones adjacent to the Magenta member at WIPP-33, leaving some subsurface cavities. This local dissolution near the eastern margin of Nash Draw is attributed to spring-sapping, as indicated by the nearby gypsite spring deposits containing camel and horse fossils. The spring-sapping and associated cliff retreat are not presently active, but probably their greatest most recent activity was contemporaneous with the now-extinct mammalian fauna. No cavities have been observed similar to those in WIPP33 in any nearby potash-exploration holes to the east (or hundreds of other holes to the east); so it is here concluded that the WIPP-33 collapse feature is unique. Despite the statement of Barrows and others (1983) that "all [gravity anomalies] are assumed to have a common origin" ( $p$ 63), karstic features are by definition associated with surface collapse; not all the gravity anomalies show surface collapse or even topographic depressions. In fact, the center of one -0.8 mgal gravity anomaly is $1 / 4 \mathrm{mi}(400 \mathrm{~m})$ east of the WIPP-14 topographic depression, which is here interpreted as a blowout. WIPP-14 contained no subsurface cavities. Thus, the "modeled gravity... from the infinitely long polygonal bodies [the assumed 'karst 
conduits']" (p 63) does not provide a unique or inescapable interpretation of the gravity data, but was evidently the interpretation preferred by Barrows and others.

The absence of true surface karst features at and near the WIPP site may be explained by the depth of burial of the Rustler Formation in that area and by the protective cover of the rocks overlying the Rustler. The Rustler is at least $500 \mathrm{ft}(152 \mathrm{~m})$ beneath the surface at the site. The overlying Dewey Lake has "minimal permeability and does not contain significant quantities of ground water.... The Dewey Lake is a protective cover that retards dissolution of evaporites in the Rustler Formation" (Mercer, 1983, p 70).

Dissolution will become a major process east of WIPP-33 only if large quantities of unsaturated water gain access to the Rustler Formation. Except for minor intermittent drainages from Livingston Ridge into Nash Draw, erosion does not appear capable of breaching the Mescalero caliche. At present, the Mescalero is an additional obstruction to infiltrating and recharging underlying beds.

Dissolution west of the indicated dissolution front in the Rustler Formation (the belt from which all halite has been dissolved from the Rustler) has occurred since late in Gatuña time (Middle Pleistocene) and continues today in Nash Draw. The area in the vicinity of WIPP-33 was above stream level and subject to erosion during Gatuña time. Dissolution at WIPP-33 is presumed to have begun then, but evidence on the surface-collapse of the Mescalero caliche and modern arroyo drainage into the collapse sink-points to post-Mescalero circulation of groundwater and consequent dissolution of remaining soluble salts. However, this modern circulation of groundwater is seasonal and probably less effective than during more humid Gatuña time. 


\section{References}

G. O. Bachman, "Cenozoic Deposits of Southeastern New Mexico and an Outline of the History of Evaporite Dissolution," USGS J of Res (2):135-149 (1976).

G. O. Bachman, Regional Geology and Cenozoic History of Pecos Region, Southeastern New Mexico, Open-File Report 80-1099 (USGS, 1980).

G. O. Bachman, Regional Geology of Ochoan Evaporites, Northern Part of the Delaware Basin, Circular 184 (Santa Fe, NM: NM Bur of Mines and Minerals, 1984).

G. O. Bachman and M. N. Machette, Calcic Soils and Calcretes in the Southwestern United States, OpenFile Report D-77-946 (USGS, 1977).

R. A. Bagnold, The Physics of Blown Sand and Desert Dunes (London: Chapman and Hall, 1973).

L. J. Barrows et al, Waste Isolation Pilot Plant (WIPP) Site Gravity Survey; and Interpretation, SAND82-2922 (Albuquerque, NM: Sandia National Laboratories, 1983).

D. J. Borns et al, Deformation of Evaporites Near the Waste Isolation Pilot Plant (WIPP) Site, SAND821069 (Albuquerque, NM: Sandia National Laboratories, 1983).

L. H. Gile, F. F. Peterson, and R. B. Grossman, "Morphological and Genetic Sequences of Carbonate Accumulation in Desert Soils," Soil Science 101(5):347-360 (1966).

L. H. Gile, J. H. Hawley, and R. B. Grossman, Soils and Geomorphology in the Basin and Range Area of Southern New Mexico-Guidebook to the Desert Project, Memoir 39 (Santa Fe, NM: New Mexico Bureau of Mines and Mineral Resouces, 1981).

R. M. Holt and D. W. Powers, Geotechnical Activities in the Waste Handling Shaft, Waste Isolation Pilot Plant (WIPP) Project, Southeastern New Mexico, WTSDTME 038 (Carlsbad, NM: US DOE, 1984).

G. A. Izett and R. E. Wilcox, Pearlette Family Ash Beds in the Western United States and Southern Canada, USGS Misc Inv. Map I-I-1325 (1982).

C. L. Jones, Salt Deposits of Los Medaños Area, Eddy and Lea Counties, NM, With Sections on Ground Water Hydrology by M. E. Cooley and Surficial Geology by G. O. Bachman, Open-File Report 4339-7 (USGS, 1973).

C. L. Jones, Test Drilling for Potash Resources: Waste Isolation Pilot Plant Site, Eddy County, NM, OpenFile Report 78-592, 2 vol (USGS, 1978).
C. L. Jones, Geological Data for Borehole ERDA-9, Eddy County, New Mexico, Open-File Report 81-469 (USGS, 1981).

C. E. Junge and R. T. Werby, "The Concentration of Chloride, Sodium, Potassium, Calcium, and Sulfate in Rain Water over the United States," J of Meteorol 15(5):417. 425 (1958).

S. J. Lambert, Dissolution of Evaporites In and Around the Delaware Basin, Southeastern New Mexico and West Texas, SAND 82-0461 (Albuquerque, NM: Sandia National Laboratories, 1983).

L. H. Lattman, "Calcium Carbonate Cementation of Alluvial Fans in Southern Nevada," Geol Soc Am Bull 84(9):3013-3028 (1973).

W. T. Lee, "Erosion By Solution and Fill," USGS Bull 760-D (1925).

V. C. Maley and R. M. Huffington, "Cenozoic Fill and Evaporite Solution in Delaware Basin, Texas and New Mexico," Geol Soc Am Bull 64(5):539-546 (1953).

J. W. Mercer, Geohydrology of the Proposed Waste Isolation Pilot Plant Site, Los Medaños Area, Southeastern New Mexico, USGS Water Res Inv Rpt 83-4016 (USGS, 1983).

W. H. Monroe, A Glossary of Karst Terminology, USGS Water Supply Paper 899 (USGS, 1970).

J. N. Rosholt, Uranium-Trend Dating of Quaternary Sediments, Open-File Report 80-1087 (USGS, 1980).

J. N. Rosholt, USGS, written communication (1979).

Sandia National Laboratories and US Geological Survey, Basic Data Report for Drillhole WIPP-33, SAND802011 (Albuquerque, NM: Sandia National Laboratories, 1981).

Sandia National Laboratories and D'Appolonia Consulting Engineers, Basic Data Report for Drillhole WIPP-14, SAND82-1783 (Albuquerque, NM: Sandia National Laboratories, 1982).

B. J. Szabo, "Uranium-Series Dating of Quaternary Successions," Proc VIII INQUA Congress (Paris, France: 1969).

US DOE, DOE Responses to the State of New Mexico's Comments on "Summary of the Results of the Evaluation of the WIPP Site and Preliminary Design Validation Program," (WIPP-DOE-161), WIPP-DOE-174 (Albuquerque, NM: USDOE, 1983). 


\section{DISTRIBUTION:}

US Department of Energy, Headquarters (2)

Office of Nuclear Waste Management

Attn: A. Follett, Project Coordinator (WIPP)

R. Stein

Washington, DC 20545

US Department of Energy (2)

Albuquerque Operations

Attn: G. C. Romatowski

D. G. Jackson, Director, Public Affairs Division

PO Box 5400

Albuquerque, NM 87185

US Department of Energy (8)

Attn: W. R. Cooper, WIPP Project Office, (Carlsbad) (2)

A. Hunt, WPO (Carlsbad) (4)

R. Crawley, WPO (Carlsbad) (2)

PO Box 3090

Carlsbad, NM 88220

US Department of Energy

Carlsbad WIPP Project Office

Room 113, Federal Building

Carlsbad, NM 88220

US Department of Energy, NPO (2)

Office of Nuclear Waste Isolation

Attn: Jeff 0 . Neff

R. Wunderlich

505 King Avenue

Columbus, OH 43201

US Department of Energy, SRPO

Office of Nuclear Waste Isolation

Attn: G. Appel

505 King Avenue

Columbus, OH 43201

US Nuclear Regulatory Commission (2)

Division of Waste Management

Attn: Michael Bell.

Hubart Miller

Mail Stop 697SS

Washington, DC 20555
Battelle Memorial Institute (9)

Project Management Division

Attn: W. Carbiener, General Manager (3)

J. Treadwell

T. Naymik

J. Kirchner

L. Page

0 . Swanson

ONWI Library

505 King Avenue

Columbus, OH 43201

Westinghouse Electric Corporation (3)

Attn: P. Miskimin

B. Rigney

Library

PO Box 2078

Carlsbad, NM 88221

IT Corporation

Attn: R. McKinney

D. Colton

J. Morse

PO Box 2078

Carlsbad, NM 88221

Bechtel Inc.

Attn: E. Weber

D. Roberts

PO Box 3965

45-11-B34

San Francisco, CA 94119

Konrad B. Krauskopf

Department of Geology

Stanford University

Stanford, CA 94305

Frank L. Parker

Department of Environmental and

Water Resources Engineering

Vanderbilt University

Nashville, TN 37235

John O. Blomeke

Oak Ridge National Laboratory

PO Box X

Oak Ridge, TN 37830 
DISTRIBUTION (cont):

John D. Bredehoeft

Western Region Hydrologist

Water Resources Division

US Geological Survey

345 Middlefield Road

Menlo Park, CA 94025

Dr. Karl P. Cohen

928 N. California Avenue

Palo Alto, CA 94303

Fred M. Ernsberger

Adjunct Professor

Department of Material Sciences and Engineering

University of Florida

Gainsville, FL 32611

Hans P. Eugster

Department of Earth Sciences

Johns Hopkins University

Baltimore, MD 21218

Rodney C. Ewing

University of New Mexico

Department of Geology

Albuquerque, NM 87131

Charles Fairhurst

Department of Geological Sciences

University of Minnesota

Minneapolis, MN 55455

William R. Muehlberger

Department of Geological Sciences

University of Texas at Austin

Austin, TX 78712

D'Arcy A. Shock

233 Virginia

Ponca City, OK 74601

National Academy of Sciences

Committee on Radioactive Waste Management

Attn: John T. Holloway, Senior Staff Officer

2101 Constitution Avenue, NW

Washington, DC 20418

Hobbs Public Library

Attn: Ms. Marcia Lewis, Librarian

509 N. Ship Street

Hobbs, NM 88248
New Mexico Tech

Martin Speere Memorial Library

Campus Street

Socorro, NM 87801

New Mexico State Library

Attn: Ms. Ingrid Vollenhofer

PO Box 1629

Santa Fe, NM 87503

University of New Mexico

Zimmerman Library

Attn: Zanier Vivian

Albuquerque, NM 87131

Atomic Museum, Kirtland East AFB

WIPP Public Reading Room

Attn: Ms. Gwynn Schreiner

Albuquerque, NM 87185

Carlsbad Municipal Library

WIPP Public Reading Room

Attn: Lee Hubbard, Head Librarian

$101 \mathrm{~S}$. Hallagueno St.

Carlsbad, NM 88220

Thomas Brannigan Library

Attn: Don Dresp, Head Librarian

106 W. Hadley St.

Las Cruces, NM 88001

Roswell Public Library

Attn: Ms. Nancy Langston

301 N. Pennsylvania Avenue

Roswell, NM 88201

State of New Mexico (3)

Environmental Evaluation Group

Attn: Robert H. Neill, Director

320 Marcy Street

PO Box 968

Santa Fe, NM 87503

NM Department of Energy and Minerals (2)

Attn: Larry Kehoe, Secretary

Kasey LaPlante, Librarian

PO Box 2770

Santa Fe, NM 87501 


\section{DISTRIBUTION (cont):}

Dr. D. K. Mukherjee

Ontario Hydro Research Lab

800 Kipling Avenue

Toronto, Ontario

CANADA

MBZ 554

Institue für Tieflagerung (3)

Attn: K. Kühn

N. Jockwer

H. Gies

Theodor-Heuss-Strasse 4

D-3300 Braunschweig

FEDERAL REPUBLIC OF GERMANY

Michael Langer

Bundesanstalt für Geowissenschaften und Rohstoffe

Postfach 510153

3000 Hannover 51

FEDERAL REPUBLIC OF GERMANY

Klaus Eckart Maass

Hahn-Meitner-Institut für Kernforschung

Glienicker Strasse 100

1000 Berlin 39

FEDERAL REPUBLIC OF GERMANY

Rolf-Peter Randl

Bundesministerium für Forschung und Technologie

Postfach 200706

5300 Bonn 2

FEDERAL REPUBLIC OF GERMANY

Helmut Rothemeyer

Physikalisch-Technische Bundesanstalt

Bundesanstalt 100, 3300 Braunschweig

FEDERAL REPUBLIC OF GERMANY

Kernforschung Karlsruhe (2)

Attn: R. Koster

Reinhard Kraemer

Postfach 3640

7500 Karlsruhe

FEDERAL REPUBLIC OF GERMANY

Svensk Karnbransleforsorjning AB

Project KBS

Karnbranslesakerhet

Attn: Fred Karlsson

Box 5864

10248 Stockholm

SWEDEN
Tuen Deboer, Mgr.

Experimental Programs

Underground Storage of Radioactive Waste

3 Westerduinweg

PO Box 1

$1755 \mathrm{ZG}$

Petten

THE NETHERLANDS

Argonne National Laboratory

Attn: S. Fried

9700 South Cass Avenue

Argonne, IL 60439

Battelle Pacific Northwest Laboratories

Attn: D. J. Bradley

Battelle Boulevard

Richland, WA 99352

US Nuclear Regulatory Commission (3)

Division of Waste Management

Attn: M. Bell

Mail Stop 69755

Washington, DC 20555

IT Corporation (3)

Attn: D. Stephanson

D. Shukla

T. Dillon

Suite 103

2350 Alamo, SE

Albuquerque, NM 87106

C. S. Fore

Ecological Sciences Information Center

Oak Ridge National Laboratory - Bldg. 2001

PO Box X

Oak Ridge, TN 37830

John Handin

Center of Tectonophysics

Texas A\&M University

College Station, TX 77840

D. E. Large

US Department of Energy

Research \& Technical Support Division

PO Box E

Oak Ridge, TN 37830 


\section{DISTRIBUTION (cont):}

Paul W. Levy, Senior Scientist

Brookhaven National Laboratory

Associated Universities, Inc.

Upton, NY 11973

Los Alamos National Laboratory

Attn: B. Erdal, CNC-11

Los Alamos, NM 87545

University of Minnesota

Dept. of Energy and Materials Science

Attn: R. Oriani

151 Amundson Hall

421 Washington Avenue SE

Minneapolis, MN 55455

Oak Ridge National Laboratory (4)

Attn: R. E. Blanko

E. Bondietti

C. Claiborne

G. H. Jenks

Box Y

Oak Ridge, TN 37830

George Pinder

Department of Civil Engineering

Princeton University

Princeton, NJ 08540

Dr. R. O. Pohl

Department of Physics

Clark Hall

Cornell University

Ithaca, NY 14853

RE/SPEC Inc.

Attn: P. Gnirk

PO Box 725

Rapid City, SD 57701

RE/SPEC, Inc.

Attn: S. W. Key

PO Box 14984

Albuquerque, NM 87191

Rockwell International (2)

Atomics International Division

Rockwell Hanford Operations

Attn: M. J. Smith

W. W. Schultz

PO Box 800

Richland, WA 99352
E. Roedder

US Department of the Interior

959 National Center

Geological Survey

Reston, VA 22092

Dr. Shosei Serata

Serata Geomechanics

1229 Eighth Street

Berkeley, CA 94170

US Department of Energy (2)

Division of Waste Products

Attn: G. H. Daly

J. E. Dieckhoner

Mail Stop B-107

Washington, DC 20545

New Mexico Bureau of Mines and Mineral Resources

(2)

Attn: F. E. Kottolowski, Director

J. Hawley

Socorro, NM 87801

US Department of Energy (2)

Idaho Operations Office

Nuclear Fuel Cycle Division

Attn: R. M. Nelson

J. Whitsett

550 Second Street

Idaho Falls, ID 83401

US Department of Energy (2)

Savannah River Operations Office

Waste Management Project Office

Attn: J. R. Covell

D. Fulmer

PO Box A

Aiken, SC 29801

US Geological Survey

Special Projects

Attn: R. Snyder

MS954, Box 25046

Denver Federal Center

Denver, CO 80255

US Geological Survey

PO Box 26659

Albuquerque, NM 87125 


\section{DISTRIBUTION (cont):}

US Geological Survey

Conservation Division

Attn: W. Melton

PO Box 1857

Roswell, NM 88201

University of Arizona (2)

Department of Nuclear Engineering

Attn: J. G. McCray

J. J. K. Daemen

Tuscon, AZ 85721

Fenix \& Scisson, Inc.

Attn: J. A. Cross

3170 W. Sahara Avenue

Spanish Oaks D-12

Las Vegas, NV 89102

University of New Mexico

Geology Department

Attn: D. G. Brookins

Albuquerque, NM 87131

Woodward-Clyde Consultants (2)

Library Western Region

Attn: Anne T. Harrigan, Librarian Charles Taylor

3 Embarcadero Center, Suite 700

San Francisco, CA 94111

Michigan Technological University

Department of Social Sciences

Center for Waste Management Programs

Attn: G. L. Downey

Houghton, MI 49931

D. W. Powers

Department of Geological Sciences

University of Texas at El Paso

El Paso, TX 79902

G. O. Bachman (10)

Star Route

Box 1028

Corrales, NM 87048
1540 W. C. Luth

1543 J. L. Krumhansl

3310 W. D. Burnett

6000 E. H. Beckner

6253 D. A. Northrop

6253 A. R. Sattler

6257 J. K. Linn

6257 R. R. Beasley

6300 R. W. Lynch

6310 T. O. Hunter

6312 F. W. Bingham

6313 T. E. Blejwas

6314 J. R. Tillerson

6315 S. Sinnock

6330 W. D. Weart

6331 A. R. Lappin (5)

6331 G. E. Barr

6331 R. L. Beauheim

6331 D. J. Borns

6331 D. M. Harvey

6331. S. J. Lambert (20)

6331 W. B. Miller

6331 K. L. Robinson

6331 S. E. Shaffer

6331 C. L. Stein

6332 L. D. Tyler

6332 F. G. Yost

6332 Sandia WIPP Central Files (Dissolution) (2)

7100 C. D. Broyles

7130 J. D. Kennedy

7133 R. D. Statler

7133 C. W. Gulick

7133 J. W. Mercer

7135 P. D. Seward

8024 M. A. Pound

3141 C. M. Ostrander (5)

3151 W. L. Garner (3)

3154-3 C. H. Dalin (28)

For DOE/TIC (Unlimited Release) 